\title{
论文
}

\section{中国沙漠元素地球化学区域特征及其对黄土 物源的指示意义}

赵万苍 ${ }^{1,2}$, 刘连文 ${ }^{2}$, 陈骏 ${ }^{2}$, 季峻峰 $^{2^{*}}$

1. 西南大学地理科学学院, 岩溶环境重庆市重点实验室, 重庆 400715;

2. 南京大学地球科学与工程学院, 表生地球化学教育部重点实验室, 南京 210023

* 通讯作者, E-mail: Jijunfeng@nju.edu.cn

收稿日期：2018-09-21; 收修改稿日期：2019-02-18; 接受日期：2019-04-03; 网络版发表日期：2019-05-28

国家自然科学基金项目(批准号: 41673095、41230526、41690111和41877369)和中央高校基本业务费项目(编号: Swu118203)资助

摘要沙漠释放的矿物尘是大气气溶胶的重要组分之一.中国北方干旱半干旱沙漠、沙地和中国北方戈壁及邻 近的蒙古国戈壁(下文简称戈壁)是亚洲风尘的潜在源区. 然而, 矿物尘源区常量元素特征缺少系统研究. 本研究采 集中国北方 12 个沙漠(地)及中蒙边境戈壁 310 个流动或半流动沙丘地表沙样, 结合前人发表的数据, 系统分析了中 国沙漠表层样品常量元素特征, 结果表明中国沙漠常量元素存在明显的区域差异性, 可分四个区: (1) 西部的塔克 拉玛干、库姆塔格、柴达木沙漠; (2) 中西部的巴丹吉林、腾格里、库布其和毛乌素沙漠; (3) 东北的呼伦贝尔、 浑善达克和科尔沁沙地; (4) 戈壁和古尔班通古特沙漠. 中国沙漠的 $\mathrm{SiO}_{2}$ 和 $\mathrm{CaO}$ 含量变化较大, $\mathrm{SiO}_{2}$ 平均含量总体 上呈现西低东高的变化趋势, $\mathrm{CaO}$ 平均含量呈现西高东低的变化趋势 $\left(\mathrm{SiO}_{2}\right.$ 和 $\mathrm{CaO}$ 平均含量在西部沙漠分别为 $64.5 \%$ 和 $7.8 \%$; 戈壁为 $71.3 \%$ 和 $2.2 \%$; 中西部沙漠 $77.6 \%$ 和 $2.1 \%$; 东北沙地 $85.7 \%$ 和 $0.8 \%$ ). 沙漠常量元素含量变化 主要受控于两个方面: 源区岩石的组成和新鲜物质的供给. 西部沙漠新鲜物质供应充分, $\mathrm{SiO}_{2} /\left(\mathrm{Al}_{2} \mathrm{O}_{3}+\mathrm{K}_{2} \mathrm{O}+\mathrm{Na}_{2} \mathrm{O}\right)$ 低, 源岩具有高铁镁质和高碳酸盐物质的特征; 而东北沙地缺少新鲜物质供应, $\mathrm{SiO}_{2} /\left(\mathrm{Al}_{2} \mathrm{O}_{3}+\mathrm{K}_{2} \mathrm{O}+\mathrm{Na}_{2} \mathrm{O}\right)$ 高, 原岩 含钾长石等花岗岩物质，表现高 $\mathrm{SiO}_{2}$ 和 $\mathrm{K}_{2} \mathrm{O}$ 含量特征。通过 $\mathrm{SiO}_{2} / 10-\mathrm{CaO}-\mathrm{Al}_{2} \mathrm{O}_{3} 、\left(\mathrm{~K}_{2} \mathrm{O}+\mathrm{Na} 2 \mathrm{O}\right)-\mathrm{CaO}-\mathrm{Fe} \mathrm{O}_{2}$ 和 CaO$\mathrm{Na}_{2} \mathrm{O}-\mathrm{K}_{2} \mathrm{O}$ 等三角图解可较好地将各个区域的沙漠加以区分. 黄土丰富的碳酸盐矿物, 结合 $\mathrm{Fe}_{2} \mathrm{O}_{3} / \mathrm{Al}_{2} \mathrm{O}_{3}$ 和 $\mathrm{K}_{2} \mathrm{O} / \mathrm{Al}_{2}$ $\mathrm{O}_{3}$ 等其他元素地球化学特征, 我们认为西部与中西部沙漠可能是黄土高原黄土潜在的物源区.

关键词沙漠, 黄土, 常量元素, 风尘, 碳酸盐

\section{1 引言}

晚新生代以来, 随着青藏高原隆升, 副特提斯海的 收缩并退出, 以及全球逐渐变冷, 中国地区大气环流由
行星风系转为季风风系, 来自海洋的水汽向盆地输送 受到阻碍，加之越过高原后气流的焚风效应，亚洲内 陆趋于干旱化, 山前盆地沉积物经过风蚀等地表过程 产生大量风沙, 并源源不断地得到高山上的风化/剥蚀 
物质供给, 从而形成了广衰的沙漠、戈壁(鹿化煜和郭 正堂, 2013; Zheng, 2016; 郭正堂, 2017). 干旱化和半干 旱化的沙漠/沙地中颗粒较粗的砂, 在地表风作用下相 互碰撞并产生大量的细颗粒物质, 被风吹扬并被搬运 至下风向相对平坦的高地或盆地, 形成典型的粉尘堆 积, 构成了现代的黄土高原与沙漠共存的环境格局, 其历史可追寻至22 25Ma以前(Guo等, 2002; 强小科 等, 2010; Zheng等, 2015). 在合适的地貌与气候的双 重作用下, 中国北方及邻近的蒙古等亚洲内陆地区, 提 供大量粉砂物质(Smalley, 1995; Zheng, 2016), 成为全 球重要的风尘释放中心之一(Engelbrecht和Derbyshire, 2010). 这些释放的风尘影响大气化学组分、气候变 化、生物地球化学循环以及人类健康等. 因此, 研究 这些沙漠、戈壁地区的元素、矿物和同位素等地球化 学特征, 有助于辨识风尘的传输途径, 帮助理解不同尺 度风尘排放和传输动力的控制机制和揭示风尘记录的 古环境信息.

近年，众多研究对中国黄土、沙漠和戈壁开展了 大量的元素、同位素和矿物学的工作. 早在 20 世纪 90 年代, 刘从强等通过元素和 $\mathrm{Sr}-\mathrm{Nd}$ 探讨黄土高原黄土物 源就认为塔克拉玛干沙漠是黄土的重要源区( Liu等, 1993, 1994). 季峻峰等(1997)通过伊利石类型和结晶度 研究认为黄土伊利石来自青藏高原祁连低变质岩. 孙 继敏等基于矿物、元素比和 $\mathrm{Sr}-\mathrm{Nd}$ 等同位素研究认为, 准噶尔盆地、塔里木盆地和柴达木盆地不是黄土物源 区，中蒙交接的戈壁沙漠及南部的巴丹吉林、腾格 里、乌兰布和、库布其和毛乌素沙漠才是黄土主要物 源区, 且戈壁阿尔泰和祁连山高山过程产生的物质才 是黄土的来源(Sun, 2002). 后来, 有研究者也利用 Sr$\mathrm{Nd}$ 同位素示踪研究, 认为塔克拉玛干沙漠、内蒙古中 西部、青藏高原东北部沙漠可能是黄土源区(饶文波 等, 2006; 杨杰东等, 2007). 然而, 近年台站观测结合现 代遥感观测技术表明, 亚洲沙尘多发生在春季, 呈现两 个多发区, 一个位于塔克拉玛干沙漠, 另一个为祁连山 与戈壁阿尔泰山之间广衰的干旱区(Shao和Dong, 2006; 陈思宇等, 2017). 另外, 单颗粒锆石、石英自旋 信号及 $\delta^{18} \mathrm{O}$ 等物源指标研究也揭示塔克拉玛干、古尔 班通古特、巴丹吉林、腾格里沙漠和蒙古戈壁的物质 来源与附近构造抬升有关(李高军, 2010; Sun等, 2007, 2013). Pullen等(2011)用单颗粒锆石技术研究认为柴达 木盆地是黄土的物源. 陈骏和李高军(2011)通过白云
石碳氧同位素研究将黄土高原黄土物源限定在塔克拉 玛干沙漠和祁连山山麓和阿拉善干旱区. 李乐等用铀 同位素 $\left({ }^{234} \mathrm{U} /{ }^{238} \mathrm{U}\right)$ 研究发现黄土高原物质来自戈壁沙 漠、鄂尔多斯干旱区和祁连山北缘(Li等, 2018). 众多 结果表明沙漠和戈壁的物质组成受构造控制, 其物质 主要来源于中亚造山带和青藏高原北缘沙漠, 具有二 源性特征(Chen等, 2007; 陈骏和李高军, 2011; Zhao 等, 2014).

相对来说，中国沙漠、戈壁和蒙古国戈壁沙漠的 元素组成、特别是常量元素组成特征, 主要以单个沙 漠的工作为主，如Yang等(2007)、 Hu和Yang(2016)等, 分别分析了塔克拉玛干沙漠、巴丹吉林沙漠的常量与 稀土元素组成, 研究了各沙漠的常量元素特征及其物 源指示意义; 但尚缺少众多沙漠常量元素对比等系统 的研究. 沙尘从沙漠释放前, 往往经历多次的沉积旋 回并得到一定程度的混合, 决定常量元素变化的主要 矿物受源岩的物质组成、风化剥蚀作用、搬运迁移的 分选作用以及沉积后改源等多种因素的影响(Bauluz 等, 2000; Smalley, 1995). 但通过系统比较沙漠沉积物 常量元素变化, 仍有可能获取各个沙漠的地球化学特 征, 为风尘的示踪提供帮助, 值得进一步研究.

基于本次工作的数据并结合前人发表的大量结 果, 本文综合分析了中国沙漠与中国北方戈壁及邻近 的蒙古国戈壁(下文统称戈壁)的常量元素组成, 借此 揭示亚洲风尘潜在源区的常量元素地球化学特征.

\section{2 研究区概况与样品}

中国沙漠(含半干旱的沙地)、戈壁集中连片分布 于北方地区 $\left(35^{\circ} \mathrm{N} \sim 50^{\circ} \mathrm{N}, 75^{\circ} \mathrm{E} \sim 125^{\circ} \mathrm{E}\right)$ 中纬度温带干旱 和半干旱气候区, 呈弧形带状分布(图1). 受新生代青 藏高原阶段性隆升影响, 青藏高原北缘形成了现代盆山地貌格局(朱震达等, 1980; 方小敏等, 2001; 刘嘉琪 和秦小光, 2005; 王国灿等, 2011). 由于高原地势格局 和大气环流的共同作用, 自东向西, 腾格里、巴丹吉林 和塔克拉玛干沙漠的干旱度逐步增强, 腾格里北部沙 漠以固定、半固定沙丘为主外, 巴丹吉林和塔克拉玛 干沙漠以流动沙丘为主. 古尔班通古特沙漠由于天山 阻隔作用, 截留了部分来自西伯利亚的湿气, 其降水 量较大，以固定、半固定沙丘为主. 而中国东北沙地 (科尔沁、呼伦贝尔和浑善达克沙地)伴有草地和森林 
草原，属于半干旱沙地. 构造上，西部沙漠中的塔克拉 玛干、库姆塔格沙漠位于塔里木陆块区(晋宁造山时 期1000 850Ma), 柴达木沙漠位于柴达木地块之上, 其 可能与扬子陆块具有亲缘性，原特提斯的形成造成塔 里木陆块和扬子大陆的裂解(辛后田等, 2006). 塔克拉 玛干沙漠以东的巴丹吉林、腾格里沙漠位于阿拉善陆 块之上，毛乌素沙地、库布其沙地位于鄂尔多斯陆块 之上，贺兰山被陆缘盆地夹在中间，将毛乌素、库布 齐和腾格沙漠里分开. 在中亚造山带上(天山-兴蒙造 山系), 自西向东依次分布着古尔班通古特、蒙古戈 壁、浑善达克、呼伦贝尔和科尔沈沙地，其突出特征 是受板块碰撞影响，形成独特的走滑挤压下的盆山格 局(Tapponnier和Molnar, 1976).

在前人研究的基础上，本次工作在中国北方 12 个 沙漠及戈壁新增 310 个地表沙样样品. 沙漠样品以流 动或半流动沙丘为主, 采样深度 $<30 \mathrm{~cm}$, 蒙古国戈壁采 自戈壁上干河床和相对低洼地表层沙 $(<30 \mathrm{~cm})$, 样品间 隔5 100km(采样细节见Sun等，2013)(图1). 样品采用 全样分析, 研磨至 200 目以下, 称取烘干后的 $1 \mathrm{~g}$ 粉末样 品以四嗍酸锂 $\left(\mathrm{LiB}_{4} \mathrm{O}_{7}\right)$ 和偏硼酸锂 $\left(\mathrm{LiBO}_{2}\right)$ 做熔融剂, 用溴化锂 $(\mathrm{LiBr})$ 做脱水剂在铂金坩埚熔融制成透明饼 状，然后利用南京大学现代分析中心ARL9800XP+型 $\mathrm{X}$ 射线荧光光谱仪测定常量元素，测试结果经标样控
制和对照实验加入标准样和平行样品进行测试质量的 控制, 分析误差优于 $5 \%$.

\section{3 结果}

\section{1 中国沙漠和戈壁常量元素特征}

中国沙漠样品全岩常量元素分析结果列于表1中, 各沙漠全岩常量元素含量结果与文献报导相应沙漠数 据(表2)基本一致(Hu和Yang，2016；Liu和Yang，2013; Liu B等, 2016; Maher等, 2009; Wang等, 2012; Yang等, 2007). 从表1中可以看出, 中国沙漠全岩样品常量元素 的分布具有以下特点: (1) 各个沙漠 $\mathrm{SiO}_{2}$ 含量较高且变 化较大，总体呈现西低东高，其中，西部的塔克拉玛 干、柴达木和古尔班通古特沙漠的 $\mathrm{SiO}_{2}$ 平均含量较低 (低于 $70 \%$, 本文中百分比均为质量百分比), 与上部大 陆地壳(UCC)组成较接近(图2), 而其余沙漠的 $\mathrm{SiO}_{2}$ 含 量较高, 特别是东北的呼伦贝尔、浑善达克和科尔沁 三大沙地, 其 $\mathrm{SiO}_{2}$ 平均含量高达 $85 \%$ 左右. (2) $\mathrm{CaO}$ 含 量的变化范围较大, 总体呈现西高东低, 其中西部的塔 克拉玛干和柴达木沙漠的 $\mathrm{CaO}$ 平均含量高达 $8 \%$ 以上, 而东北的呼伦贝尔和浑善达克沙地的 $\mathrm{CaO}$ 平均含量低 于 $1 \%$. (3) 由于 $\mathrm{SiO}_{2}$ 的含量明显高于 $\mathrm{UCC}$, 中国沙漠的 $\mathrm{Al}_{2} \mathrm{O}_{3} 、 \mathrm{TiO}_{2} 、 \mathrm{Fe}_{2} \mathrm{O}_{3} 、 \mathrm{Na}_{2} \mathrm{O} 、 \mathrm{MgO}$ 和 $\mathrm{P}_{2} \mathrm{O}_{5}$ 相对UCC 亏

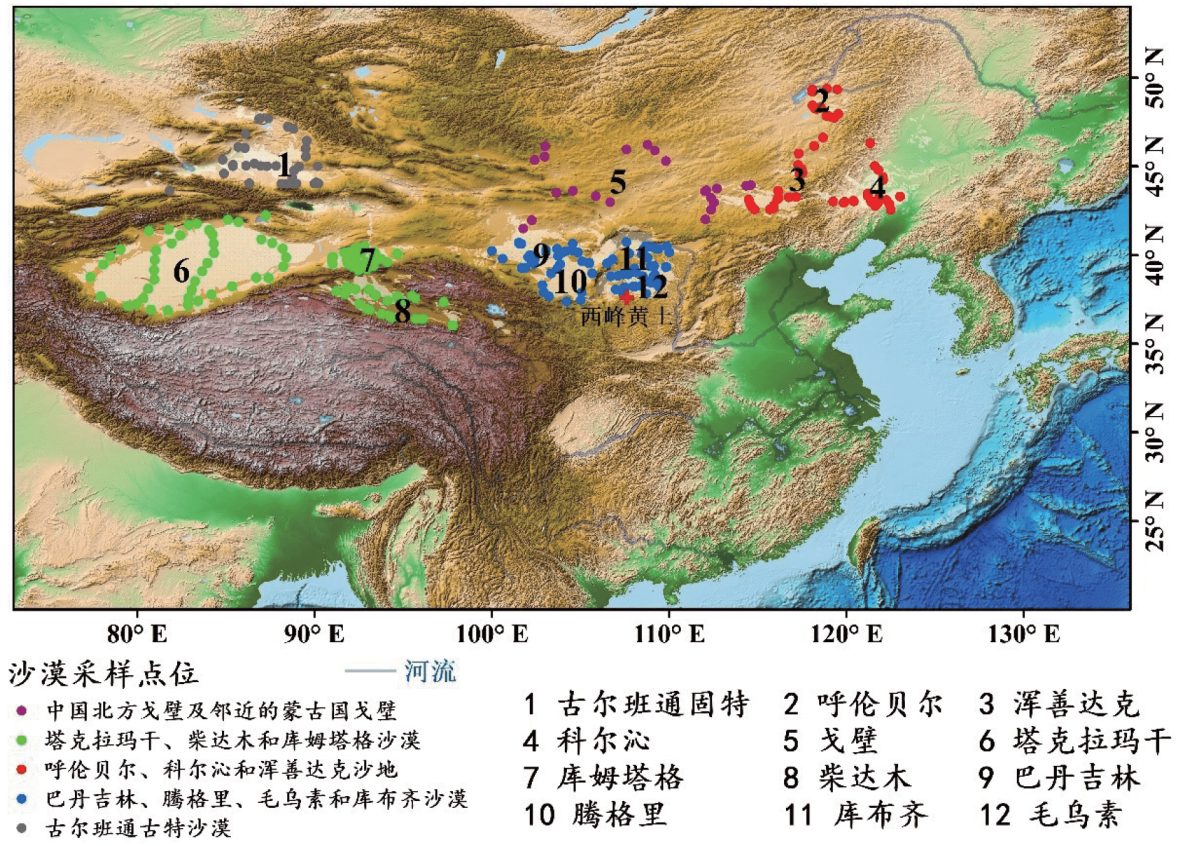

图 1 研究区及样品点位图 
赵万苍等: 中国沙漠元素地球化学区域特征及其对黄土物源的指示意义

表 1 各沙漠全岩常量元素含量统计表

\begin{tabular}{|c|c|c|c|c|c|c|c|c|c|c|c|c|c|}
\hline 沙漠 & & 样数 $(n)$ & & $\mathrm{SiO}_{2}$ & $\mathrm{TiO}_{2}$ & $\mathrm{Al}_{2} \mathrm{O}_{3}$ & $\mathrm{Fe}_{2} \mathrm{O}_{3}$ & $\mathrm{MnO}$ & $\mathrm{MgO}$ & $\mathrm{CaO}$ & $\mathrm{Na}_{2} \mathrm{O}$ & $\mathrm{K}_{2} \mathrm{O}$ & $\mathrm{P}_{2} \mathrm{O}_{5}$ \\
\hline \multirow{6}{*}{ 西部沙漠 } & \multirow{3}{*}{ 塔克拉玛干 } & \multirow{3}{*}{37} & 最大值 & 72.5 & 0.98 & 14.2 & 5.27 & 0.111 & 2.98 & 17.27 & 3.54 & 2.82 & 0.151 \\
\hline & & & 平均值 & 64.9 & 0.52 & 10.6 & 2.96 & 0.067 & 2.04 & 7.69 & 2.38 & 2.09 & 0.103 \\
\hline & & & 最小值 & 50.2 & 0.14 & 7.2 & 2.01 & 0.039 & 1.46 & 2.70 & 1.40 & 1.67 & 0.058 \\
\hline & \multirow{3}{*}{ 柴达木 } & \multirow{3}{*}{22} & 最大值 & 78.0 & 0.71 & 11.3 & 3.78 & 0.070 & 3.06 & 29.20 & 5.68 & 2.88 & 0.140 \\
\hline & & & 平均值 & 60.7 & 0.33 & 8.5 & 2.06 & 0.047 & 1.60 & 11.18 & 2.46 & 1.96 & 0.070 \\
\hline & & & 最小值 & 30.4 & 0.14 & 5.4 & 1.17 & 0.030 & 0.52 & 3.54 & 1.50 & 1.06 & 0.035 \\
\hline \multirow{12}{*}{ 中西部沙漠 } & \multirow{3}{*}{ 巴丹吉林 } & \multirow{3}{*}{23} & 最大值 & 87.0 & 0.49 & 10.6 & 3.46 & 0.070 & 1.92 & 3.98 & 2.93 & 2.29 & 0.080 \\
\hline & & & 平均值 & 79.9 & 0.30 & 8.5 & 2.10 & 0.039 & 1.04 & 1.83 & 2.08 & 1.89 & 0.047 \\
\hline & & & 最小值 & 72.7 & 0.10 & 5.8 & 0.94 & 0.020 & 0.40 & 0.90 & 1.40 & 1.37 & 0.020 \\
\hline & \multirow{3}{*}{ 库布其 } & \multirow{3}{*}{26} & 最大值 & 83.6 & 0.57 & 13.3 & 4.53 & 0.077 & 2.82 & 7.96 & 3.53 & 3.02 & 0.147 \\
\hline & & & 平均值 & 77.9 & 0.30 & 10.2 & 1.86 & 0.034 & 0.73 & 1.95 & 2.47 & 2.32 & 0.048 \\
\hline & & & 最小值 & 56.4 & 0.14 & 7.3 & 1.01 & 0.020 & 0.35 & 0.88 & 1.58 & 1.77 & 0.024 \\
\hline & \multirow{3}{*}{ 毛乌素 } & \multirow{3}{*}{30} & 最大值 & 84.7 & 0.67 & 13.0 & 2.42 & 0.070 & 1.24 & 5.40 & 3.56 & 3.07 & 0.082 \\
\hline & & & 平均值 & 77.8 & 0.30 & 10.4 & 1.64 & 0.033 & 0.65 & 1.88 & 2.68 & 2.41 & 0.044 \\
\hline & & & 最小值 & 69.6 & 0.13 & 6.2 & 0.90 & 0.019 & 0.32 & 0.60 & 1.38 & 1.68 & 0.018 \\
\hline & \multirow{3}{*}{ 腾格里 } & \multirow{3}{*}{23} & 最大值 & 81.6 & 0.49 & 12.1 & 3.21 & 0.065 & 1.69 & 4.56 & 3.54 & 3.14 & 0.060 \\
\hline & & & 平均值 & 77.3 & 0.35 & 9.5 & 2.31 & 0.041 & 1.11 & 2.15 & 2.11 & 2.38 & 0.044 \\
\hline & & & 最小值 & 71.0 & 0.26 & 8.1 & 1.78 & 0.027 & 0.70 & 0.73 & 1.39 & 1.86 & 0.030 \\
\hline \multirow{9}{*}{ 东北沙地 } & \multirow{3}{*}{ 呼伦贝尔 } & \multirow{3}{*}{23} & 最大值 & 91.8 & 0.34 & 9.3 & 1.77 & 0.038 & 0.45 & 1.79 & 1.91 & 3.46 & 0.061 \\
\hline & & & 平均值 & 87.9 & 0.13 & 6.0 & 0.64 & 0.015 & 0.18 & 0.41 & 1.17 & 2.46 & 0.021 \\
\hline & & & 最小值 & 79.9 & 0.04 & 3.9 & 0.30 & 0.007 & 0.07 & 0.17 & 0.75 & 1.84 & 0.000 \\
\hline & \multirow{3}{*}{ 浑善达克 } & \multirow{3}{*}{26} & 最大值 & 90.9 & 0.30 & 9.3 & 1.97 & 0.040 & 1.02 & 2.58 & 2.04 & 3.49 & 0.047 \\
\hline & & & 平均值 & 85.4 & 0.16 & 7.3 & 0.82 & 0.020 & 0.27 & 0.53 & 1.50 & 2.76 & 0.021 \\
\hline & & & 最小值 & 79.9 & 0.06 & 4.6 & 0.35 & 0.010 & 0.06 & 0.16 & 0.81 & 1.92 & -0.004 \\
\hline & \multirow{3}{*}{ 科尔沁 } & \multirow{3}{*}{21} & 最大值 & 94.3 & 0.51 & 11.6 & 2.37 & 0.051 & 1.72 & 7.99 & 2.58 & 3.25 & 0.072 \\
\hline & & & 平均值 & 84.8 & 0.16 & 6.9 & 0.89 & 0.019 & 0.40 & 1.22 & 1.30 & 2.53 & 0.026 \\
\hline & & & 最小值 & 66.2 & 0.04 & 2.6 & 0.34 & 0.003 & 0.12 & 0.06 & 0.47 & 1.21 & -0.005 \\
\hline \multirow{6}{*}{$\begin{array}{c}\text { 中国北方戈壁及邻 } \\
\text { 近蒙古戈壁和古尔 } \\
\text { 班通古特沙漠 }\end{array}$} & \multirow{3}{*}{$\begin{array}{l}\text { 中国北方戈壁 } \\
\text { 和蒙古戈壁 }\end{array}$} & \multirow{3}{*}{19} & 最大值 & 83.5 & 0.71 & 16.5 & 6.29 & 0.115 & 3.17 & 5.98 & 3.23 & 5.06 & 0.203 \\
\hline & & & 平均值 & 71.7 & 0.42 & 11.6 & 2.89 & 0.062 & 1.27 & 2.15 & 2.00 & 3.08 & 0.095 \\
\hline & & & 最小值 & 52.8 & 0.18 & 7.9 & 0.95 & 0.020 & 0.22 & 0.35 & 1.09 & 2.36 & 0.020 \\
\hline & \multirow{3}{*}{ 古尔班通古特 } & & 最大值 & 94.3 & 0.79 & 16.5 & 8.54 & 0.180 & 3.97 & 11.35 & 5.63 & 3.36 & 0.300 \\
\hline & & 36 & 平均值 & 69.7 & 0.46 & 11.2 & 3.31 & 0.077 & 1.66 & 3.57 & 2.56 & 2.22 & 0.122 \\
\hline & & & 最小值 & 47.7 & 0.04 & 2.4 & 0.38 & 0.023 & 0.17 & 0.22 & 0.24 & 0.89 & 0.010 \\
\hline
\end{tabular}

损(图2). (4) 东北的呼伦贝尔、浑善达克和科尔沁沙 地的 $\mathrm{K}_{2} \mathrm{O}$ 含量高于西部和中西部沙漠，考虑到东北沙 地异常高的 $\mathrm{SiO}_{2}$ ，其 $\mathrm{K}_{2} \mathrm{O}$ 的相对富集就尤为显著. (5) 沙漠不同粒级 $(<28 \mu \mathrm{m} 、 28 \sim 75 \mu \mathrm{m} 、>75 \mu \mathrm{m})$ 的常量元 素地球化学存在差异, 随粒度变粗 $\mathrm{SiO}_{2}$ 含量升高, 而 $\mathrm{Al}_{2} \mathrm{O}_{3} 、 \mathrm{Fe}_{2} \mathrm{O}_{3} 、 \mathrm{MgO} 、 \mathrm{CaO} 、 \mathrm{TiO}_{2}$ 和烧失量 $(\mathrm{LIO})$ 降低
(网络版附图1, http://earthen.scichina.com).

\section{2 中国沙漠常量元素的区域地球化学特征}

按全岩常量元素差异，结合各个沙漠、戈壁的地 理位置，我们将中国沙漠分为西部沙漠、中西部沙 漠、东北沙地和戈壁及古尔班通古特沙漠 4 个分区， 
表 2 文献中各沙漠常量元素含量统计表 ${ }^{a)}$

\begin{tabular}{|c|c|c|c|c|c|c|c|c|c|c|c|c|}
\hline 沙漠 & & 统计项 & $\mathrm{SiO}_{2}$ & $\mathrm{TiO}_{2}$ & $\mathrm{Al}_{2} \mathrm{O}_{3}$ & $\mathrm{Fe}_{2} \mathrm{O}_{3}$ & $\mathrm{MnO}$ & $\mathrm{MgO}$ & $\mathrm{CaO}$ & $\mathrm{Na}_{2} \mathrm{O}$ & $\mathrm{K}_{2} \mathrm{O}$ & $\mathrm{P}_{2} \mathrm{O}_{5}$ \\
\hline \multirow{6}{*}{ 西部沙漠 } & \multirow{3}{*}{ 塔克拉玛干 } & 最大值 & 74.3 & 1.05 & 15.7 & 7.21 & 0.126 & 4.05 & 12.10 & 3.60 & 3.26 & 0.180 \\
\hline & & 平均值 & 64.2 & 0.45 & 10.8 & 3.08 & 0.061 & 2.15 & 7.15 & 2.56 & 2.15 & 0.100 \\
\hline & & 最小值 & 51.7 & 0.22 & 9.6 & 1.69 & 0.029 & 1.07 & 2.30 & 2.17 & 1.56 & 0.052 \\
\hline & \multirow{3}{*}{ 库姆塔格 } & 最大值 & 81.3 & 0.66 & 14.0 & 5.63 & 0.084 & 3.63 & 9.39 & 3.09 & 3.43 & 0.151 \\
\hline & & 平均值 & 71.7 & 0.38 & 10.2 & 2.75 & 0.053 & 1.71 & 4.31 & 2.59 & 2.27 & 0.079 \\
\hline & & 最小值 & 55.3 & 0.20 & 8.1 & 1.52 & 0.031 & 0.55 & 1.45 & 1.36 & 1.66 & 0.051 \\
\hline \multirow{6}{*}{ 中西部沙漠 } & \multirow{3}{*}{ 巴丹吉林 } & 最大值 & 85.2 & 1.00 & 14.0 & 6.10 & 0.085 & 4.10 & 7.39 & 3.65 & 2.68 & 0.057 \\
\hline & & 平均值 & 74.1 & 0.46 & 9.8 & 2.77 & 0.046 & 1.42 & 2.59 & 2.39 & 2.09 & 0.023 \\
\hline & & 最小值 & 54.4 & 0.22 & 6.2 & 0.97 & 0.031 & 0.41 & 1.02 & 1.58 & 1.64 & 0.007 \\
\hline & \multirow{3}{*}{ 毛乌素 } & 最大值 & 82.8 & 0.39 & 12.4 & 2.19 & 0.041 & 1.12 & 3.24 & 3.44 & 2.69 & 0.082 \\
\hline & & 平均值 & 79.1 & 0.31 & 9.7 & 1.64 & 0.032 & 0.72 & 1.74 & 2.36 & 2.26 & 0.042 \\
\hline & & 最小值 & 75.3 & 0.18 & 7.6 & 0.90 & 0.019 & 0.41 & 0.60 & 1.54 & 1.68 & 0.018 \\
\hline \multirow{3}{*}{ 东北沙地 } & \multirow{3}{*}{ 浑善达克 } & 最大值 & 90.7 & 1.38 & 10.6 & 3.42 & 0.100 & 0.56 & 1.49 & 2.69 & 3.64 & 0.050 \\
\hline & & 平均值 & 85.2 & 0.35 & 7.7 & 1.20 & 0.029 & 0.31 & 0.64 & 1.81 & 2.73 & 0.027 \\
\hline & & 最小值 & 77.8 & 0.08 & 4.9 & 0.45 & 0.010 & 0.17 & 0.24 & 1.18 & 1.86 & 0.020 \\
\hline \multirow{3}{*}{$\begin{array}{c}\text { 中国北方戈壁及 } \\
\text { 邻近蒙古戈壁 }\end{array}$} & \multirow{3}{*}{ 蒙古戈壁 } & 最大值 & 61.2 & 1.20 & 16.3 & 8.50 & 0.180 & 16.48 & 18.67 & 1.82 & 3.48 & 0.420 \\
\hline & & 平均值 & 56.2 & 0.92 & 14.5 & 6.80 & 0.132 & 4.57 & 5.66 & 1.37 & 2.79 & 0.253 \\
\hline & & 最小值 & 47.1 & 0.56 & 9.4 & 3.61 & 0.050 & 3.20 & 1.95 & 0.88 & 1.77 & 0.050 \\
\hline
\end{tabular}

a) 塔克拉玛干沙漠样品的元素含量来自Honda和Shimizu(1998)、Yang等(2007)、Zhu和Yang(2009); 库姆塔格表层样品的常量元素数组 来自Xu等(2011); 巴丹吉林样品的常量元素来自Hu和Yang(2016); 毛乌素样品的常亮元素含量来自Liu B 等(2016); 浑善达克样品的常量元素 含量来自Liu和Yang(2013); 蒙古国戈壁阿尔泰样品的常量元素含量来自Maher等(2009)

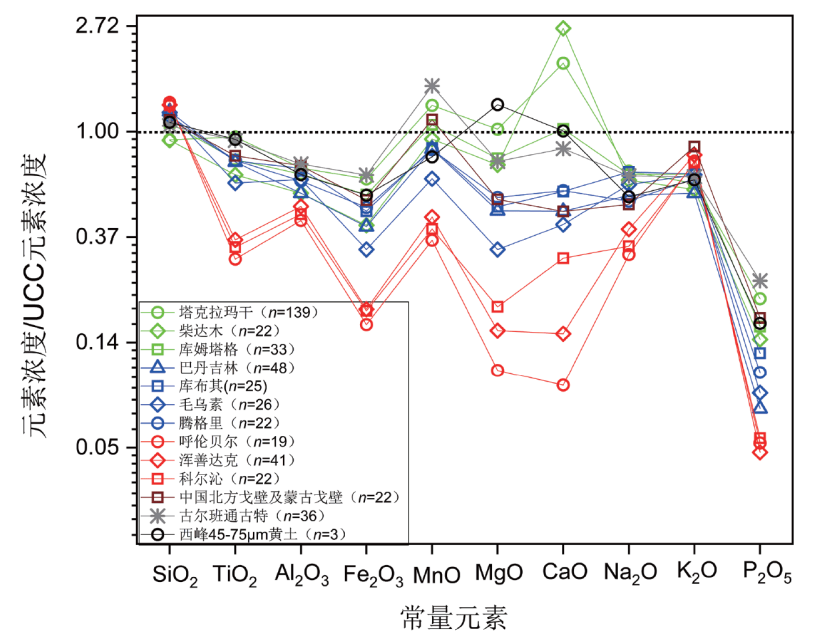

图 2 中国沙漠/沙地及中国北方戈壁及蒙古戈壁元素UCC 标准化蜘蛛图

分别讨论其元素组成特征.

(1) 西部沙漠. 青藏高原北缘在塔里木和柴达木版 块之上的塔克拉玛干、库姆塔格 $(\mathrm{Xu}$ 等, 2011) 和柴达
木沙漠以较低的 $\mathrm{SiO}_{2}(55 \sim 81.3 \%)$ 和较高的 $\mathrm{CaO}$ (1.5 27.6\%) 为主要特点, 由于 $\mathrm{SiO}_{2}$ 含量较低, $\mathrm{Al}_{2} \mathrm{O}_{3}$ 、 $\mathrm{Fe}_{2} \mathrm{O}_{3} 、 \mathrm{MnO} 、 \mathrm{MgO}$ 和 $\mathrm{Na}_{2} \mathrm{O}$ 含量相对较高(表1和图2).

(2) 中西部沙漠. 贺兰山东西两侧的巴丹吉林沙 漠、腾格里沙漠(Ren等, 2014; Hu和Yang, 2016)、库 布其和毛乌素沙漠( $\mathrm{Liu} \mathrm{B}$ 等, 2016), 以中等的 $\mathrm{SiO}_{2}$ 含量 (56.4 82.8\%) 和中等的 $\mathrm{CaO}$ 含量 $(0.6 \sim 3.3 \%)$ 为主要特 征，相应地 $\mathrm{Al}_{2} \mathrm{O}_{3} 、 \mathrm{Fe}_{2} \mathrm{O}_{3} 、 \mathrm{MgO} 、 \mathrm{MnO} 、 \mathrm{TiO}_{2} 、 \mathrm{Na}_{2} \mathrm{O}$ 和 $\mathrm{P}_{2} \mathrm{O}_{5}$ 等其他氧化物含量介于西部沙漠和东北沙地之 间(表1和图3).

(3) 东北沙地. 中国东北的呼伦贝尔、科尔沁和浑 善达克沙地(Liu和Yang, 2013)的样品以高的 $\mathrm{SiO}_{2}$ 和低 的 $\mathrm{CaO}$ 含量为特征, 其余元素除了 $\mathrm{K}_{2} \mathrm{O}$ 含量 (2.17 3.49\%)相对较高外, $\mathrm{Al}_{2} \mathrm{O}_{3} 、 \mathrm{Fe}_{2} \mathrm{O}_{3} 、 \mathrm{MgO}$ 、 $\mathrm{MnO} 、 \mathrm{TiO}_{2} 、 \mathrm{Na}_{2} \mathrm{O}$ 和 $\mathrm{P}_{2} \mathrm{O}_{5}$ 的平均含量均低于西部沙 漠和中西部沙漠(表1和图3).

(4) 戈壁和古尔班通古特沙漠. 中国北方和蒙古国 南部的戈壁沙漠表层样品的常量元素含量与中西部沙 
漠的组成较为接近, 具有中等的 $\mathrm{SiO}_{2}$ 平均含量, 其 $\mathrm{P}_{2} \mathrm{O}_{5}$ 和 $\mathrm{K}_{2} \mathrm{O}$ 平均含量较高(表1和图3). 古尔班通古特沙漠被 天山和阿勒泰等山系环绕, 地理上位于准噶尔盆地, 但 从构造上讲, 其与戈壁位于中亚造山带上, 其常量元素 含量整体上与戈壁接近(表1和图3).

\section{3 中国沙漠常量元素的变化规律}

从表1可以看出, 沙漠常量元素含量的变化范围很 大，而一个元素的富集往往伴随着其余元素的相对亏 损. 因此, 有必要分析沙漠不同元素间的相关关系, 结 合元素在沙漠中主要矿物(何同, MLA分析结果, 未发 表数据)的赋存状态，从中找出元素的变化规律，进而
揭示沙漠的地球化学特征.

(1) $\mathrm{Si}$ 与 $\mathrm{Al}$ 是沙漠中含量最高的两个常量元素. $\mathrm{SiO}_{2}$ 和 $\mathrm{Al}_{2} \mathrm{O}_{3}$ 总体呈显著的负相关(相关系数达 0.63 , $n=420$ ). 相关系数最高的是东北沙地(达 $0.90, n=44$ ), 然 后依次是戈壁，西部的塔克拉玛拉玛干、库姆塔格和 柴达木沙漠等. $\mathrm{SiO}_{2}$ 主要来自于石英和硅酸盐矿物, 而 $\mathrm{Al}_{2} \mathrm{O}_{3}$ 主要来自于长石、云母、黏土矿物等铝硅酸 盐矿物, $\mathrm{SiO}_{2}$ 和 $\mathrm{Al}_{2} \mathrm{O}_{3}$ 的显著负相关反映了沙漠中石英 对其他元素的稀释作用. 而西部的塔克拉玛拉玛干、 库姆塔格和柴达木沙漠含有较高含量的碳酸盐矿物 ( $\mathrm{Li}$ 等, 2007), 造成了 $\mathrm{SiO}_{2}$ 和 $\mathrm{Al}_{2} \mathrm{O}_{3}$ 相关系数的降低和关 系的复杂化(图3a).
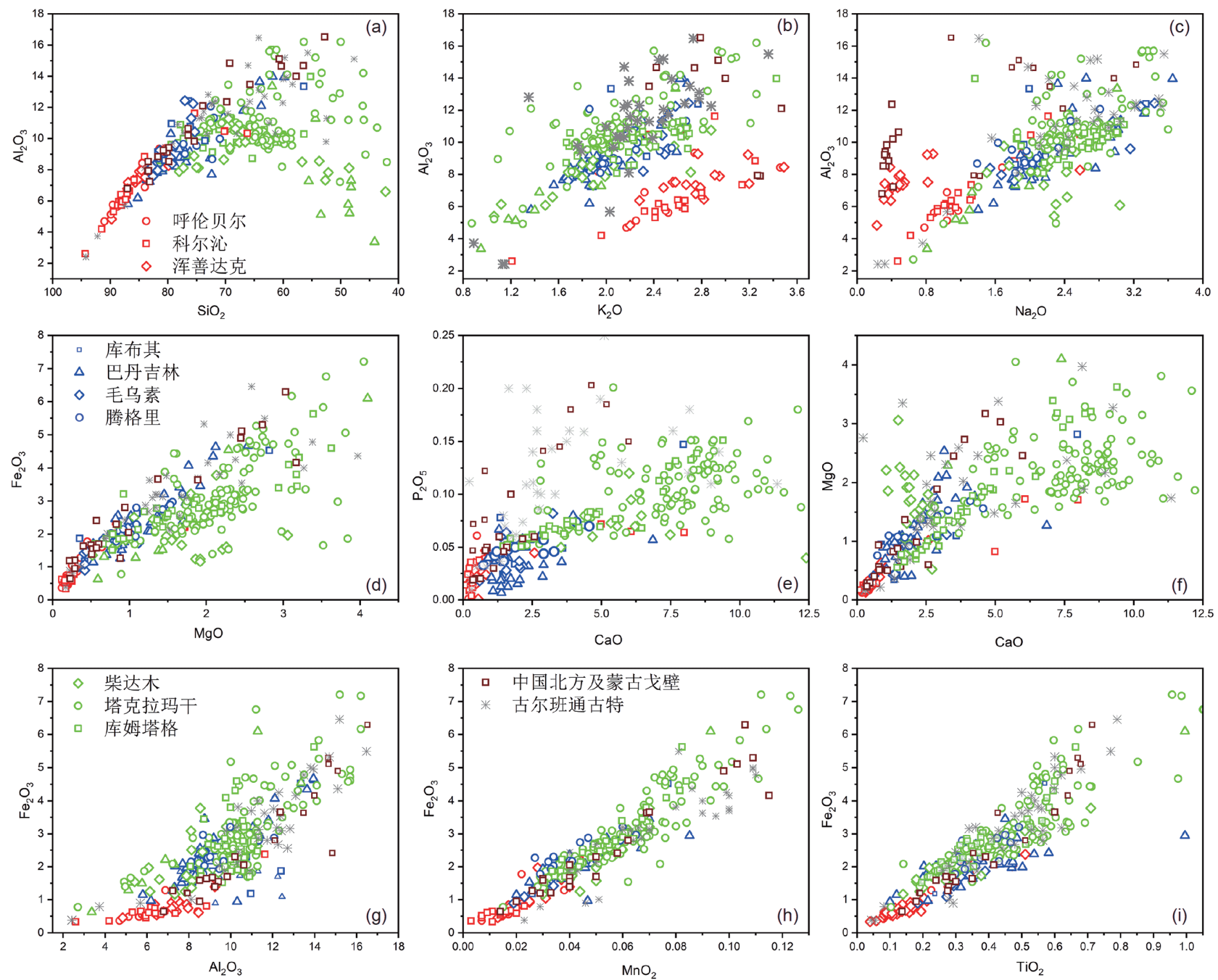

图 3 中国沙漠、沙地常量元素地球化学关系图

(a) (i) 图例见(a)、(d)、(g)和(h)所示 
(2) $\mathrm{K}_{2} \mathrm{O}$ 和 $\mathrm{Al}_{2} \mathrm{O}_{3}$ 呈现显著的正相关, 并将沙漠分成 两个不同区域，东北沙地和部分戈壁样品为一个区域, 其相关系数达 $0.68(n=44)$, 西部沙漠和中西部沙漠区域 为另一区域, 相关系数达 $0.66(n=376)$. 虽然都为显著的 正相关，但相同的 $\mathrm{Al}_{2} \mathrm{O}_{3}$ 东北沙地和部分戈壁样品中 $\mathrm{K}_{2} \mathrm{O}$ 明显更高，显示其硅酸盐中含 $\mathrm{K}$ 矿物更为丰富. $\mathrm{Na}_{2} \mathrm{O}$ 与 $\mathrm{Al}_{2} \mathrm{O}_{3}$ 也表现出显著正相关(图3c), 并呈现出分 区性, 但其分区性不如 $\mathrm{K}_{2} \mathrm{O}$ 和 $\mathrm{Al}_{2} \mathrm{O}_{3}$ 明显(图3b). 由于 $\mathrm{Na}$ 主要存在于斜长石中， $\mathrm{K}$ 主要存在于钾长石、白云母 和黏土矿物中(Jeong等, 2008), 沙漠沉积物中 $\mathrm{Na} 、 \mathrm{~K}$ 与 $\mathrm{Al}$ 的相关性，更多地反映了这些矿物的含量变化基 本同步. $\mathrm{Fe}_{2} \mathrm{O}_{3}$ 和 $\mathrm{Al}_{2} \mathrm{O}_{3}$ 亦表现出显著的正相关性, 表明 存在于铁氧化物中的 $\mathrm{Fe}(\mathrm{Lu}$ 等，2017)和赋存于铁镁硅 酸盐矿物中的 $\mathrm{Fe}$ 在沙漠形成过程中同步变化. 西部的 塔克拉玛干、库姆塔格和柴达木沙漠的 $\mathrm{Fe}_{2} \mathrm{O}_{3}$ 含量相 对较高, 而东北沙地的 $\mathrm{Fe}_{2} \mathrm{O}_{3}$ 含量偏低(图3g).

(3) $\mathrm{CaO}$ 与 $\mathrm{MgO}$ 可以以硅酸盐和碳酸盐矿物存在. 硅酸盐中, $\mathrm{Ca}$ 主要存在于斜长石、磷灰石等矿物中, 而 $\mathrm{Mg}$ 主要存在于绿泥石和少量的角闪石、辉石、黑 云母等铁镁硅酸盐矿物中，而两者共同存在于白云 石、方解石等碳酸盐矿物中. 西部和中西部沙漠中 $\mathrm{CaO}$ 与 $\mathrm{MgO}$ 总体呈较好的正相关, $\mathrm{CaO}$ 与 $\mathrm{Al}_{2} \mathrm{O}_{3}$ 之间相 关性较差, 且部分样品 $\mathrm{CaO}$ 含量高达 $15 \%$, 说明西部沙 漠中的 $\mathrm{CaO}$ 与碳酸盐的高含量有关(图3f). 东北沙地 $\mathrm{CaO}$ 与 $\mathrm{MgO}$ 含量低于中西部沙漠且关系较为复杂, 并 且 $\mathrm{CaO}$ 与 $\mathrm{Al}_{2} \mathrm{O}_{3}$ 呈现较好的正相关, 表明东北沙地中的 $\mathrm{Ca}$ 主要受控于硅酸盐矿物.

(4) 所有样品的 $\mathrm{Fe}_{2} \mathrm{O}_{3}$ 与 $\mathrm{MnO}$ 和 $\mathrm{TiO}_{2}$ 呈现显著的正 相关性(图3h和 $3 \mathrm{i}$ ), 其中, $\mathrm{Fe}_{2} \mathrm{O}_{3}$ 和 $\mathrm{MnO}$ 的相关系数达 $0.91(n=420), \mathrm{Fe}_{2} \mathrm{O}_{3}$ 与 $\mathrm{TiO}_{2}$ 的相关系数达 $0.93(n=420)$, 这表明，由于 $\mathrm{Mn} 、 \mathrm{Ti}$ 经常呈类质同象替换出现在含 $\mathrm{Fe}$ 矿物中, $\mathrm{Fe} 、 \mathrm{Ti}$ 和 $\mathrm{Mn}$ 在沙漠的形成与其后的地质过程 中, 并不产生明显分离.

(5) $\mathrm{MgO}$ 与 $\mathrm{Fe}_{2} \mathrm{O}_{3}$ 呈现明显的正相关, 特别是在东 北沙地和中西部的沙漠, $\mathrm{MgO}$ 与 $\mathrm{Fe}_{2} \mathrm{O}_{3}$ 显著正相关(图 $3 \mathrm{~d})$, 表明东北沙地和中西部的沙漠中的 $\mathrm{Fe}$ 和 $\mathrm{Mg}$ 主要 存在于铁镁硅酸盐矿物中，而且在沙漠的形成及其后 的地质过程中不易发生分离(刘连文等, 2000); 而在西 部的塔克拉玛干、库姆塔格和柴达木沙漠, 部分样品 的 $\mathrm{MgO}$ 较高, 明显偏离 $\mathrm{MgO}$ 与 $\mathrm{Fe}_{2} \mathrm{O}_{3}$ 相关线, 表明更多 的 $\mathrm{Mg}$ 来自于碳酸盐矿物, 特别是白云石对 $\mathrm{Mg}$ 的贡献
(Li等, 2007). 西部的塔克拉玛拉玛干、库姆塔格和柴 达木沙漠 $\mathrm{MgO}$ 与 $\mathrm{CaO}$ 呈现较好的正相关也反映了西部 沙漠高含量的碳酸盐矿物是 $\mathrm{MgO}$ 和 $\mathrm{CaO}$ 的主要来源 (图3f)(Li等, 2007).

\section{4 讨论}

\section{1 中国沙漠和戈壁常量元素分区}

基于中国沙漠、戈壁的常量元素含量, 有显著差 别的元素主要有四类, 分别是与石英含量变化相关的 $\mathrm{SiO}_{2}$, 反映碳酸盐含量变化的 $\mathrm{CaO}$, 指示铁镁硅酸盐与 重矿物含量变化的 $\mathrm{Fe}$ 、 $\mathrm{Ti}$ 和 $\mathrm{Mn}$, 指示长石与云母/黏土 矿物变化的 $\mathrm{K}_{2} \mathrm{O}$ 和 $\mathrm{Na}_{2} \mathrm{O}$ 等. 另外, $\mathrm{MgO}$ 的变化与碳酸 盐和铁镁硅酸盐含量变化都有关系. 为消除碳酸盐含 量变化的影响, 采用其他元素与 $\mathrm{Al}_{2} \mathrm{O}_{3}$ 比值来指示沙漠 其他元素的相对变化.

中国沙漠 $\mathrm{SiO}_{2} / \mathrm{Al}_{2} \mathrm{O}_{3}$ 反映了石英相对于其他硅酸 盐矿物的相对变化, 其平均值为8.31(n=420), $\mathrm{SiO}_{2} /$ $\mathrm{Al}_{2} \mathrm{O}_{3}$ 从低到高依次为西部沙漠的塔克拉玛干沙漠、 库姆塔格沙漠和柴达木沙漠(6.43, $n=194)$, 戈壁(7.40, $n=37$ ), 中西部沙漠的腾格里、毛乌素和库布其、巴丹 吉林沙漠 $(8.33, n=124)$, 古尔班通古特 $(8.38, n=36)$ 和东 北沙地 $(13.52, n=44)$. 西部沙漠的石英含量明显低于东 部沙地.

$\mathrm{Fe}_{2} \mathrm{O}_{3} / \mathrm{Al}_{2} \mathrm{O}_{3}$ 反映了硅酸盐矿物中铁镁硅酸盐含量 的相对变化, 其平均值为 $0.23(n=420)$; 从低到高依次为 东北沙地 $(0.11, n=44)$, 戈壁 $(0.21, n=37)$, 腾格里、毛乌 素和库布其沙漠 $(0.22, n=124)$; 西部沙漠中的巴丹吉 林、塔克拉玛干沙漠、库姆塔格沙漠和柴达木沙漠 (0.27, $n=194)$ 以及古尔班通古特沙漠 $(0.28, n=36)$. $\mathrm{CaO} / \mathrm{Al}_{2} \mathrm{O}_{3}$ 反映了碳酸盐矿物相对于硅酸盐矿物的含 量, 其平均值为 $0.41(n=420)$; 从低到高依次为东北沙地 $(0.09, n=44)$, 戈壁 $(0.16, n=37)$, 中西部沙漠的巴丹吉 林、腾格里、毛乌素和库布其沙漠 $(0.22, n=124)$, 古尔 班通古特 $(0.31, n=36)$, 塔克拉玛干沙漠、库姆塔格沙 漠和柴达木沙漠 $(0.76, n=194)$. 西部沙漠铁镁质硅酸盐 和碳酸盐矿物高于东部沙地.

$\mathrm{Na}_{2} \mathrm{O} / \mathrm{Al}_{2} \mathrm{O}_{3}$ 和 $\mathrm{K}_{2} \mathrm{O} / \mathrm{Al}_{2} \mathrm{O}_{3}$ 反映了硅酸盐矿物中斜 长石与钾长石、白云母和黏土矿物的相对含量. 中国 沙漠 $\mathrm{K}_{2} \mathrm{O} / \mathrm{Al}_{2} \mathrm{O}_{3}$ 和 $\mathrm{Na}_{2} \mathrm{O} / \mathrm{Al}_{2} \mathrm{O}_{3}$ 的平均值分别为 0.25 $(n=420)$ 和 $0.23(n=420), \mathrm{Na}_{2} \mathrm{O} / \mathrm{Al}_{2} \mathrm{O}_{3}$ 从低到高依次为戈 
壁 $(0.14, n=37)$ 、东北沙地 $(0.20, n=44)$ 、古尔班通固特 $(0.23, n=36)$, 中西部沙漠中的巴丹吉林、腾格里、毛 乌素和库布其沙漠 $(0.24, n=124)$, 西部的塔克拉玛干、 库姆塔格和柴达木沙漠 $(0.25, n=194) . \mathrm{K}_{2} \mathrm{O} / \mathrm{Al}_{2} \mathrm{O}_{3}$ 平均 值依次是东北沙地 $(0.39, n=44)$, 戈壁 $(0.23, n=37)$, 中西 部沙漠中的巴丹吉林、腾格里、毛乌素和库布其沙漠 $(0.23, n=124)$, 西部的塔克拉玛干、库姆塔格和柴达木 沙漠 $(0.21, n=194)$. 造成这一明显差异的主要原因是东 部沙地和西部沙漠中钾长石和斜长石的差异，东部沙 地钾长石含量高于西部沙漠，西部沙漠中钠长石高于 东部沙地(He等, 2016).

根据沙漠常量元素的变化规律, 采用 $\mathrm{SiO}_{2} / 10$ $\mathrm{CaO}-\mathrm{Al}_{2} \mathrm{O}_{3}$ (图4a)、( $\left.\mathrm{K}_{2} \mathrm{O}+\mathrm{Na}_{2} \mathrm{O}\right)-\mathrm{CaO}-\mathrm{Fe}_{2} \mathrm{O}_{3}$ (图4b)和
$\mathrm{CaO}-\mathrm{Na}_{2} \mathrm{O}-\mathrm{K}_{2} \mathrm{O}$ (图4c) 三角图解来区分各个沙漠的区 域特征. 其中 $\mathrm{SiO}_{2} / 10-\mathrm{CaO}-\mathrm{Al}_{2} \mathrm{O}_{3}$ 反映了样品中石英-碳 酸盐-硅酸盐矿物的相对含量变化; $\left(\mathrm{K}_{2} \mathrm{O}+\mathrm{Na}_{2} \mathrm{O}\right)-\mathrm{CaO}$ $\mathrm{Fe}_{2} \mathrm{O}_{3}$ 反映了样品中长石-碳酸盐-铁镁质硅酸盐矿物的 相对含量变化; 而 $\mathrm{CaO}-\mathrm{K}_{2} \mathrm{O}-\mathrm{Na}_{2} \mathrm{O}$ 反映了样品中碳酸 盐-斜长石-钾长石/白云母的相对含量变化. 在图 $4 \mathrm{a}$ 中, 西部沙漠以显著高的碳酸盐矿物和较低的石英、中等 含量的硅酸盐矿物为特征，东北沙地以显著高的石英 矿物为特征, 其余沙漠落于三角图中部. 在图 $4 \mathrm{~b}$ 中, 西 部沙漠以高的碳酸盐矿物含量和高的铁镁质矿物为特 征，而东北沙地的长石含量较高，戈壁样品较为分散， 部分样品落于东北沙地区域、部分样品落于三角图中 部, 中西部样品则主要落于三角图中部. 在图 $4 \mathrm{c}$ 中, 东
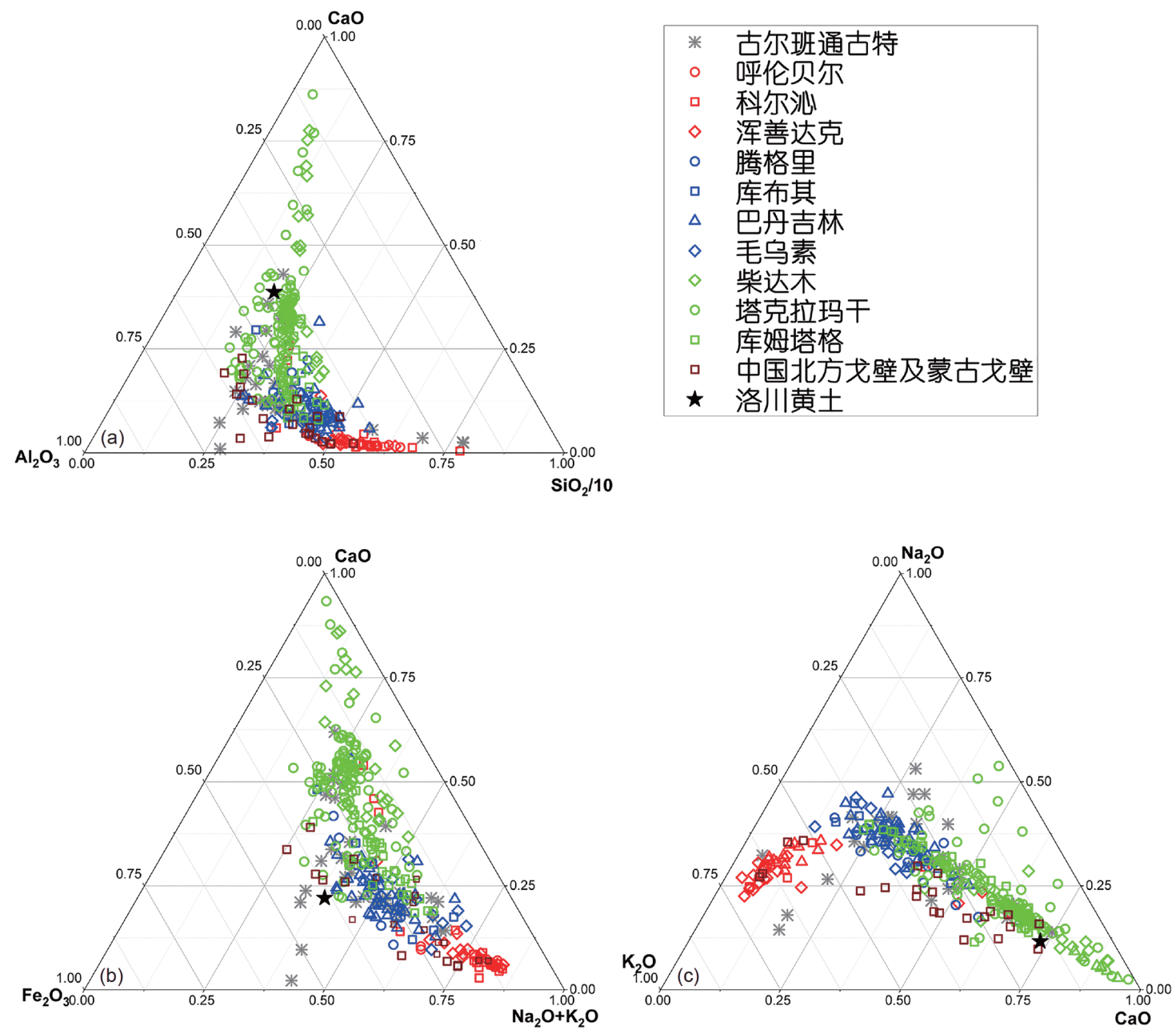

图 4 中国沙漠、沙地、及洛川黄土常量元素地球化学元素三角图

(a) $\mathrm{SiO}_{2} / 10-\mathrm{CaO}-\mathrm{Al}_{2} \mathrm{O}_{3}$; (b) $\left(\mathrm{Na}_{2} \mathrm{O}+\mathrm{K}_{2} \mathrm{O}\right)-\mathrm{CaO}-\mathrm{Fe}_{2} \mathrm{O}_{3}$; (c) $\mathrm{CaO}-\mathrm{Na}_{2} \mathrm{O}-\mathrm{K}_{2} \mathrm{O}$ 
北沙地和戈壁部分样品以高的钾长石/白云母为特征.

\section{2 控制中国沙漠常量元素含量变化的主要因素}

中国沙漠表层物质常量元素地球化学特征受构造 制约下的地表形态、物质来源和碎屑矿物组成控制, 即地质构造背景控制沙漠物质来源、构建和混合. 因 此，形成沙漠的区域背景与构造地貌相似或相近，其 物质来源和物质构成可能会相对一致. 分析中国沙漠 的常量元素组成及制约沙漠物源的构造背景，常量元 素变化主要受控于两个方面因素: 源区岩石的组成与 新鲜物质的供给造成的不同沙漠矿物成熟度差异.

常量元素变化的首要因素是源区岩石的组成, 集 中体现在中国沙漠的 $\mathrm{CaO}$ 和 $\mathrm{K}_{2} \mathrm{O}$ 含量变化上(图2和3). 西部的柴达木、塔克拉玛干沙漠中 $\mathrm{CaO}$ 含量明显高于 其他东部沙漠/沙地, 这与他们富含碳酸盐矿物有关 $(\mathrm{Li}$ 等, 2007). 虽然沙漠形成后的物理风化造成碳酸盐矿 物颗粒变细并与其他较细的黏土等硅酸盐矿物一起优 先被风搬运到其他地区，但Ca、Al间较差的相关性可 以排除这点(图3e). 沙漠形成后的化学风化会造成碳 酸盐矿物淋失, 但沙漠总体降雨量很低, 并且缺少外 流河将溶解的 $\mathrm{Ca}$ 离子带走, 碳酸盐的溶解淀积对沙漠 样品的 $\mathrm{CaO}$ 含量影响很少. 降雨量比沙漠更高的黄土 高原地区，其黄土沉积仍保存了大量的碳酸盐矿物 (Meng等，2015). 已有证据表明中国多数沙漠物源的 近源性(朱震达等, 1980; 陈骏和李高军, 2011; 付旭东 和王岩松, 2015; Hu和Yang, 2016), 沙漠沉积物来自于 周边的山脉. 从区域地球化学图上可以看出(谢学锦, 2012), 昆仑山脉分布有大量的海相碳酸盐岩, 通过河 流为周边的塔克拉玛干和柴达木沙漠源源不断地提供 了碳酸盐矿物, 造成这两个沙漠明显高的 $\mathrm{CaO}$ 含量. 库 姆塔格周边的北山地区, 分布有石炭纪的碳酸盐岩, 古 尔班通古特沙漠周边的天山、阿尔泰山都有碳酸盐岩 分布(谢学锦, 2012), 巴丹吉林沙漠、腾格里沙漠、库 布其和毛乌素沙漠周边的祁连山北缘、阿拉善周边山 脉及贺兰山南段均有碳酸盐地层分布，但规模和范围 远不如昆仑山脉, 尤其鄂尔多斯地区裸露的碳酸盐地 层分布更少(Li等, 2007; 李高军, 2010; 谢学锦, 2012). 因此, 这些沙漠的 $\mathrm{CaO}$ 含量低于西部柴达木、塔克拉 玛干沙漠. 而东北的呼伦贝尔、科尔沈和浑善达克沙 地, 其周边缺乏碳酸岩地层, 较低 $\mathrm{CaO}$ 含量体现了这一 点. 图 $2 \mathrm{~b}$ 中 $\mathrm{K}_{2} \mathrm{O}$ 和 $\mathrm{Al}_{2} \mathrm{O}_{3}$ 存在两个分区, 说明不同地区
沙漠 $\mathrm{K}$ 的来源存在很大差异. 东北沙地 $\mathrm{K}_{2} \mathrm{O}$ 含量较高, 这可能与东北地区存在富钾花岗岩、富钾玄武岩和二 长花岗岩(Liu J Q等, 2016)有关, 这些富 K岩石风化剥 蚀并被输送至浑善达克、科尔沁和呼伦贝尔沙地, 造 成沙漠样品的 $\mathrm{K}_{2} \mathrm{O}$ 含量较高. 部分中国和蒙古国相连 的戈壁样品靠近东北沙地, 也具有 $\mathrm{K}_{2} \mathrm{O}$ 含量较高的特 征. 上述元素变化趋势, 尤其是 $\mathrm{CaO}$ 的空间变化, 与李 高军等(2010)通过XRD技术获得的风尘潜在源区方解 石/石英和白云石/石英最强峰比值趋势一致, 进一步表 明沙漠中沉积物控制碳酸盐矿物含量与剥蚀区地质背 景密切相关, 而碳酸盐地层分布与其控制的 $\mathrm{CaO}$ 等常 量元素分布基本吻合. 沙漠周边山脉的基岩类型决定 沙漠沉积物石英 $\delta^{18} \mathrm{O}$ (付旭东和杨小平, 2004; 付旭东 和王岩松, 2015), 这些证据均表明沙漠沉积物由其周 边源岩控制. 从区域构造上看, 常量元素分布差异特征 与前期研究发现的构造控制的 Sr-Nd和Nd-Hf同位素 分区基本一致(Chen等, 2007; Zhao等, 2014), 这也暗示 了自西向东各沙漠物质源岩的变化控制其地球化学元 素的差异.

影响中国沙漠化学组成的第二个因素是新鲜物质 的供给. 这可从源区物质剥蚀、风化、搬运和沉积后 再变化等多个方面进行分析. 化学风化造成碳酸盐矿 物溶解, 长石、铁镁硅酸盐矿物逐渐转变为次生的黏 土矿物, 风化产物以溶液或悬浮物的形式搬运, 在粗 粒级中石英等抗风化的矿物相对富集. 物理风化会使 碳酸盐、铁镁硅酸盐矿物等抗物理风化能力较弱的矿 物受到进一步的破碎, 造成粗粒级中石英等抗风化的 矿物相对富集, 而碳酸盐、铁镁硅酸盐矿物、斜长石 等较易破碎的矿物在悬浮物中较为富集. 在分选良好 的条件下, 溶液或悬浮物被输送到海洋等较远的区域, 而较粗的砂粒物质在沉积盆地沉积, 造成沉积物化学 成份发生变化; 虽然也有证据表明河流的搬运过程中, 石英/长石的比值并不随搬运距离而变化(Nesbitt和 Young, 1996; Potter等, 2001). 首先, 从源区的物质的剥 蚀供应和物理化学风化上看, 不同沙漠差异显著. 在西 部沙漠, 如塔克拉玛干沙漠, 四周有天山、帕米尔、昆 仑山和阿尔金山等高山环抱, 河流落差大, 植被覆盖 少, 山顶有大面积冰雪分布(第四纪冰期时冰川更为发 育), 物理剥蚀能力强, 化学风化弱, 第四纪以来在塔里 木盆地堆积了 $500 \mathrm{~m}$ 以上沉积物, 即使是现代, 仍通过 塔里木河等河流为沙漠源源不断地提供大量的物质. 
而东部沙地，其源区(如西辽河的大兴安岭)有较好的 植被覆盖, 物理风化弱、化学风化强、物质供应少, 其沙地主要是草原退化起砂造成的, 缺少新鲜物质的 供应. 而在中西部沙漠, 如发源于祁连山的巨厚冲积 物和湖积物, 为巴丹吉林沙漠、腾格里沙漠等中西部 沙漠提供了物质来源, 其规模和物理、化学风化强度 都介于上述两个区域之间. 其次, 从搬运的方式与结 果看, 西部沙漠以内流河为主, 沙漠就是最终的沉积 盆地, 悬浮物和溶解物都全部进入了沉积盆地, 因此, 分选差, 含有大量的细粒物质. 而在东部沙地, 河流以 外流河为主, 悬浮物和溶解物大多进入了海洋, 供给沙 漠的主要是分选较好的砂粒物质. 最后, 从沙漠形成后 的物理、化学风化作用看, 西部沙漠以流动沙丘为主, 物理风化强、化学风化弱, 而东部沙地以固定沙区为 主, 物理风化弱, 化学风化强.

可通过矿物的成熟度来反映上述地质过程的综合 作用. 矿物成熟度是指碎屑沉积物中石英相对于碳酸 盐、长石和岩屑等含量的比值(Ruxton, 1968; Blatt等, 1972; Pettijohn等, 1972), 可用 $\mathrm{SiO}_{2}-\left(\mathrm{Al}_{2} \mathrm{O}_{3}+\mathrm{K}_{2} \mathrm{O}+\mathrm{Na}_{2} \mathrm{O}\right)$ (Muhs, 2004)(图5a)或 $\mathrm{SiO}_{2}-\left(\mathrm{Al}_{2} \mathrm{O}_{3}+\mathrm{K}_{2} \mathrm{O}+\mathrm{Na}_{2} \mathrm{O}+\mathrm{CaO}\right.$ $+\mathrm{MgO}$ )(图5b)来表示. 从图 5 可以看出, 西部塔克拉玛 干、柴达木和库姆塔格等沙漠的成熟度低, 临近的高 山隆升和局地气候变化引起剥蚀/风化增强, 源源不断 地为沙漠提供了充足的碎屑物质, 具有较低的 $\mathrm{SiO}_{2}$ 含 量和较高的 $\mathrm{Fe} 、 \mathrm{Mg}\left(\mathrm{Lu}\right.$ 等, 2017)、 $\mathrm{P}$ 含量, 其 $\mathrm{SiO}_{2} /$ $\left(\mathrm{Al}_{2} \mathrm{O}_{3}+\mathrm{K}_{2} \mathrm{O}+\mathrm{Na}_{2} \mathrm{O}\right)$ 比值为4.21( $\left.n=194\right)$ (图4c). 与西部 沙漠性质较接近的是古尔班通古特沙漠, 接受天山和 阿勒泰等剥蚀物质, 其 $\mathrm{SiO}_{2} /\left(\mathrm{Al}_{2} \mathrm{O}_{3}+\mathrm{K}_{2} \mathrm{O}+\mathrm{Na}_{2} \mathrm{O}\right)$ 比值为 4.17. 而东北的呼伦贝尔、科尔沁和浑善达克沙地, 南 部为华北克拉通, 周边地势平坦, 缺少新鲜的高山剥蚀 物质供给, 其物质组成 $\mathrm{SiO}_{2} /\left(\mathrm{Al}_{2} \mathrm{O}_{3}+\mathrm{K}_{2} \mathrm{O}+\mathrm{Na}_{2} \mathrm{O}\right)$ 平均值 高达 8.26 , 具有较高的 $\mathrm{SiO}_{2}$ 含量和较低的 $\mathrm{Fe} 、 \mathrm{Mg} 、 \mathrm{P}$ 含量. 贺兰山东西两侧的巴丹吉林沙漠、腾格里沙 漠、库布其和毛乌素沙漠, 虽然接受周边祁连山、贺 兰山的剥蚀物质供应, 但其物质供应有限, 其 $\mathrm{SiO}_{2} /$ $\left(\mathrm{Al}_{2} \mathrm{O}_{3}+\mathrm{K}_{2} \mathrm{O}+\mathrm{Na}_{2} \mathrm{O}\right)$ 平均值为 5.89. 沙漠 $\mathrm{SiO}_{2} /\left(\mathrm{Al}_{2} \mathrm{O}_{3}\right.$ $+\mathrm{K}_{2} \mathrm{O}+\mathrm{Na}_{2} \mathrm{O}$ ) 的值呈现明显的西低东高的趋势(图 $5 \mathrm{c}$ ).

西部沙漠主要分布在秦祁昆造山系与中亚造山带 之间的华北克拉通和塔里木克拉通之上(Zheng等, 2013; 刘训等, 2012; 潘桂棠等, 2009), 被一系列山系圈 围而成, 四周高山的隆升和局地气候变化引起剥蚀/风
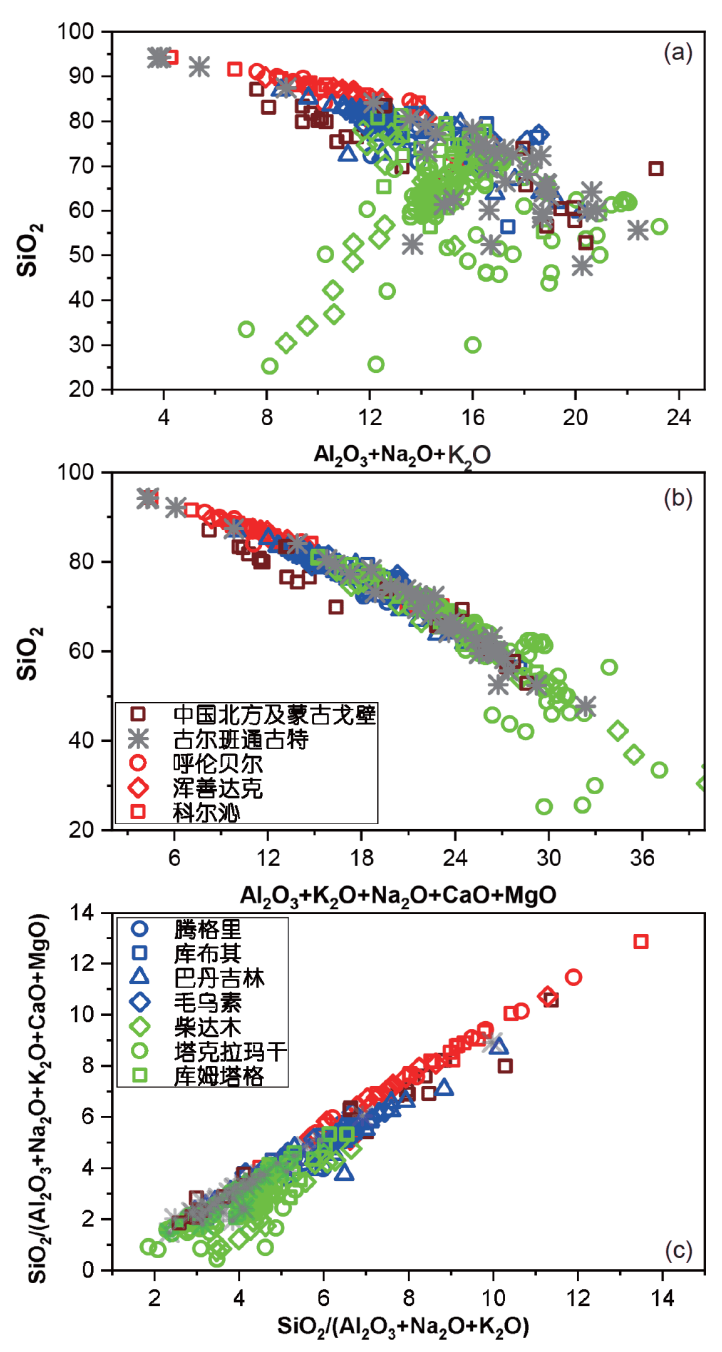

图 5 沙漠沉积物常量元素表示的石英相对于碳酸盐、长 石和岩屑示意图

化增强, 源源不断地为沙漠提供了充足的碎屑物质, 古 尔班通固特沙漠和中国和蒙古国相连的戈壁沙漠与蒙 古高原隆升后来自阿勒泰或其他高山物质剥蚀供应有 关(Chen等, 2007; 陈骏和李高军, 2011; Hu和Yang, 2016); 中亚造山带南部边缘的戈壁出露玄武岩( Liu J $\mathrm{Q}$ 等, 2016), 碱质组分高的火山岩含量也是形成常量元 素分布差异的原因之一. 而东北沙地南部为华北克拉 通, 东北沙地北部很少或几乎没有太古代和古元古代 的基底岩石(Badarch等, 2002; Zheng等, 2013; 刘训等, 2012; 潘桂棠等, 2009), 加之中亚造山带物质的剥蚀/ 风化, 进而导致中国东北沙地和中国西北沙漠物质源 的差异, 体现出东北沙地与西部沙漠常量元素地球化 
学的差异. 而科尔沁沙地南部受燕山河流输入影响, 不 排除有来自燕山少数物质的输入 (谢静和丁仲礼, 2007; Zhao等, 2014), 少数几个科尔沁的样品远离东北 沙地所属范围也验证了燕山物质对科尔沁沙地有贡献 (图3). 总之, 中国沙漠表层样品常量元素的差异受高 原隆升, 亚洲内陆干旱化和亚洲季风气候等因素共同 控制, 是其源岩剥蚀风化的综合体现, 但长期风化累 积造成的地球化学常量元素差异仍需要深入研究(Hu 和Yang, 2016; Yang等, 2007; Zhu和Yang, 2009; 罗万银 等, 2014; 王立强和王亲, 2013).

\section{3 沙漠常量元素组成对黄土物源的启示}

中国的沙漠/沙地、中国和蒙古国相连的戈壁释 放的粉砂物质受大气环流向东或东南方向传输驱动, 粉砂物质堆积于下风向, 形成世界规模最大的黄土沉 积. 从沙漠到黄土, 地表物质经过高山作用、风蚀以 及其他机械搬运充分混合, 可代表大面积区域物质的 平均组成. 从沙漠到黄土的搬运过程中, 如石英等抗 机械破碎和抗化学风化重矿物不易破碎, 较难形成可 供风力搬运的粉砂颗粒, 而粉砂质的物质优先搬运沉 积. 因此, 虽然黄土继承了沙漠源区物质的组成特征, 但黄土化学组成与沙漠化学组成并不完全一致, 如黄 土的 $\mathrm{SiO}_{2} /\left(\mathrm{Al}_{2} \mathrm{O}_{3}+\mathrm{K}_{2} \mathrm{O}+\mathrm{Na}_{2} \mathrm{O}\right)$ 比值为 $2.10 \sim 4.06$ (陈骏等, 2001; 刘连文, 2002; Xiong等, 2010), 低于最低的塔克 拉玛干沙漠, 说明在沙漠向黄土的搬运过程中, 物质产 生分异, 难以破碎的石英等被大量留在了沙漠, 比较重 的磁性矿物不易吹走进而导致沙漠磁化率高于黄土 (Maher等, 2009). 黄土沉积受风力强弱与源区远近的 控制, 黄土的颗粒大小在空间与时间序列上有所不同. 冬季风强时, 离源区近时, 颗粒较粗, 反之相反. 而颗粒 大小的变化一定程度上影响了黄土的化学组成(刘东 生, 1985; 郭正堂和彭淑贞, 2001). Si、Na等元素更趋 向于在粗颗粒中富集, $\mathrm{Fe} 、 \mathrm{Al} 、 \mathrm{~K}$ 和 $\mathrm{Mg}$ 等元素倾向于 在细颗粒中富集. 黄土沉积后受成壤作用的影响, 加 之空间化学风化差异造成黄土化学组分时空上存在变 化. 夏季风强时, 靠近东南地区的黄土沉积受较多的降 水作用的影响, 风化成壤作用强, $\mathrm{Ca} 、 \mathrm{Na} 、 \mathrm{Mg}$ 等元素 淋失(陈骏等, 2001; 刘连文, 2002). 各种复杂的空间地 理因素, 造成了利用常量元素组成来追踪黄土源区的 困难. 但从反映碳酸盐含量的 $\mathrm{Ca}$ 和反映硅酸盐矿物变 化的 $\mathrm{Al} 、 \mathrm{~K}$ 和 $\mathrm{Fe}$ 等元素在沙漠与黄土中的分布特征,
仍可找到沙漠与黄土的潜在联系.

中国黄土高原黄土的一个显著特征是含有丰富的 碳酸盐矿物(刘东生, 1985), 碳酸盐矿物容易溶解与沉 淀, 其含量存在明显的时空差异(Meng等, 2015). 比较 潜在源区、黄土和现代沙尘中的碳酸盐含量, 可为黄 土中的碳酸盐矿物的来源提供信息( $\mathrm{Li}$ 等, 2007; Wang 等, 2005). 黄土中普遍含较高的碳酸盐矿物, 如用风化 很弱的西部曹县黄土层来代表黄土的碳酸盐含量(约 15\%)(Meng等，2015), 其不可能来源于后期的成壤作 用, 沙漠的碳酸盐矿物显然是他们最主要的来源. 虽 然巴丹吉林沙漠、腾格里沙漠、库布其和毛乌素沙漠 处于黄土高原上风向, 也可为黄土高原提供一部分的 碳酸盐. 黄土的 $\mathrm{CaO} / \mathrm{Al}_{2} \mathrm{O}_{3}$ 值高达 0.86 , 远大于巴丹吉 林沙漠、腾格里沙漠、库布其和毛乌素沙漠 $\mathrm{CaO} / \mathrm{Al}_{2}$ $\mathrm{O}_{3}$ 的平均值 $(0.24)$, 这一差别较难用硅酸盐矿物和碳酸 盐矿物从沙漠到黄土搬运沉积过程中的差异性来解 释, 如东北沙地的 $\mathrm{CaO} / \mathrm{Al}_{2} \mathrm{O}_{3}$ 值平均为 0.11 , 而与此相 应的东北地区黄土 $\mathrm{CaO} / \mathrm{Al}_{2} \mathrm{O}_{3}$ 值平均为 0.17 (Xie和 Chi, 2016), 碳酸盐矿物的相对富集不到两倍. 从碳酸盐矿 物含量看, 只有西部的塔克拉玛干、库姆塔格和柴达 木沙漠 $\left(\mathrm{CaO} / \mathrm{Al}_{2} \mathrm{O}_{3}\right.$ 值为 0.76$)$ 的加入, 才能较为合理地 解释黄土高原黄土中较高的碳酸盐矿物含量的来源. 塔克拉玛干、库姆塔格和柴达木沙漠的石英 $\delta^{18} \mathrm{O}$ 值与 黄土的石英 $\delta^{18} \mathrm{O}$ 值无显著性差异(张峰和付旭东, 2016; 霍俊澎等, 2018), 也暗示了西部沙漠是黄土高原黄土 潜在的源(饶文波等, 2006; Pullen等, 2011; 李高军, 2010; 陈骏和李高军, 2011). 这一结论也与Sr-Nd同位 素物源研究一致(Chen等, 2007).

硅酸盐矿物的组成也反映了源区的信息. 从图 2 可 以看出, 同一区域的沙漠中, $\mathrm{K} 、 \mathrm{Al}$ 和 $\mathrm{Fe}$ 变化高度一致, 这种一致性有望在黄土中得以继承. $\mathrm{Fe}_{2} \mathrm{O}_{3} / \mathrm{Al}_{2} \mathrm{O}_{3}$ 和 $\mathrm{K}_{2} \mathrm{O} / \mathrm{Al}_{2} \mathrm{O}_{3}$ 等反映了样品的铁镁硅酸盐矿物与钾长石/ 云母的相对变化, 且这些指标较少受风力分选作用影 响, 是进行源区示踪的较好参数. 如西峰 $45 \sim 75 \mu \mathrm{m}$ 黄土 的 $\mathrm{Fe}_{2} \mathrm{O}_{3} / \mathrm{Al}_{2} \mathrm{O}_{3}$ 平均值为 0.27 (刘连文, 2002), 白水 $20 \sim 63 \mu \mathrm{m}$ 黄土和红黏土 $\mathrm{Fe}_{2} \mathrm{O}_{3} / \mathrm{Al}_{2} \mathrm{O}_{3}$ 平均值分别为 0.29 和 0.31(Xiong等, 2010), 以上较粗颗粒黄土的 $\mathrm{Fe}_{2} \mathrm{O}_{3}$ $/ \mathrm{Al}_{2} \mathrm{O}_{3}$ 值介于西部的塔克拉玛干沙漠、柴达木和库姆 塔格沙漠(平均值分别为 $0.30 、 0.24$ 和 0.27 )与中西部的 巴丹吉林沙漠、腾格里沙漠、库布其和毛乌素沙漠 (平均值分别为 $0.24 、 0.26 、 0.22$ 和 0.17 ) 之间. 西峰 
$45 \sim 75 \mu \mathrm{m}$ 黄土的 $\mathrm{K}_{2} \mathrm{O} / \mathrm{Al}_{2} \mathrm{O}_{3}$ 平均值为 0.21 (刘连文, 2002), 白水 $20 \sim 63 \mu \mathrm{m}$ 黄土和红黏土 $\mathrm{K}_{2} \mathrm{O} / \mathrm{Al}_{2} \mathrm{O}_{3}$ 平均值 均为 0.20 (Xiong等, 2010), 比较接近中西部沙漠(0.21) 和西部沙漠(0.23), 而明显区别于东北沙地的 $\mathrm{K}_{2} \mathrm{O} / \mathrm{Al}_{2} \mathrm{O}_{3}$ 值 (平均值为 0.44 ). 比较沙漠、沙地样品与黄土较粗颗 粒硅酸盐组分中的 $\mathrm{Fe}_{2} \mathrm{O}_{3} / \mathrm{Al}_{2} \mathrm{O}_{3}$ 和 $\mathrm{K}_{2} \mathrm{O} / \mathrm{Al}_{2} \mathrm{O}_{3}$ 值, 我们认 为西部沙漠和中西部沙漠是黄土高原黄土潜在的物 源. 从图5的三角图中可以看出, 典型的洛川黄土落在 西部沙漠或中西部沙漠之间, 而偏离东北沙地较远. 这 表明西部的塔克拉玛干沙漠、柴达木和库姆塔格沙漠 与中西部的巴丹吉林沙漠、腾格里沙漠、库布其和毛 乌素沙漠混合是中国黄土重要的来源. 另外, 中国和蒙 古国相连的戈壁样品成份较为复杂, 难以厘清其与黄 土的关系(Sun, 2002; Chen等, 2007; Maher等, 2009; Sun等, 2013).

\section{5 结论}

（1）中国沙漠地表物质的常量元素含量存在明显 的区域性差异，可分为四个区：东北沙地、中国和蒙 古国相连的戈壁和古尔班通古特沙漠、中西部沙漠和 西部沙漠. $\mathrm{SiO}_{2}$ 与 $\mathrm{CaO}$ 含量变化较大, $\mathrm{SiO}_{2}$ 呈现西低东 高的趋势; $\mathrm{CaO}$ 趋势与 $\mathrm{SiO}_{2}$ 相反, 呈现西高东低. 东北 的呼伦贝尔、浑善达克和科尔沈沙地的 $\mathrm{K}_{2} \mathrm{O}$ 含量相对 较高. 由于 $\mathrm{SiO}_{2}$ 的稀释作用, 中国沙漠相对UCC 损 $\mathrm{Al}_{2} \mathrm{O}_{3} 、 \mathrm{TiO}_{2} 、 \mathrm{Fe}_{2} \mathrm{O}_{3} 、 \mathrm{Na}_{2} \mathrm{O} 、 \mathrm{MgO} 、 \mathrm{P}_{2} \mathrm{O}_{5}$ 和 $\mathrm{MnO}$.

(2) 沙漠的元素含量变化主要受控于两个方面: 源 区岩石组成与新鲜物质供给. 沙漠表层沉积物反映了 沙漠周边的区域构造特征，西部沙漠和中西部沙漠受 构造隆升影响, 新鲜物质供应充分, 成熟度低, $\mathrm{SiO}_{2} /$ $\mathrm{Al}_{2} \mathrm{O}_{3}+\mathrm{K}_{2} \mathrm{O}+\mathrm{Na}_{2} \mathrm{O}$ 值低. 而东北沙地, 构造稳定, 缺少 新鲜物质供应, 成熟度高, $\mathrm{SiO}_{2} / \mathrm{Al}_{2} \mathrm{O}_{3}+\mathrm{K}_{2} \mathrm{O}+\mathrm{Na}_{2} \mathrm{O}$ 值高. 西部沙漠源区提供了大量的碳酸盐矿物, 其 $\mathrm{CaO}$ 高, 而 东部沙地其原岩含有钾长石等花岗岩物质, 以 $\mathrm{K}_{2} \mathrm{O}$ 含 量高为特征. 通过 $\mathrm{SiO}_{2} / 10-\mathrm{CaO}-\mathrm{Al}_{2} \mathrm{O}_{3} 、\left(\mathrm{~K}_{2} \mathrm{O}+\mathrm{Na}_{2} \mathrm{O}\right)$ $\mathrm{CaO}-\mathrm{Fe}_{2} \mathrm{O}_{3}$ 和 $\mathrm{CaO}-\mathrm{Na}_{2} \mathrm{O}-\mathrm{K}_{2} \mathrm{O}$ (图4), 以及常量元素体现 的相对长石与碳酸盐差异(网络版附图 2, http://earthen. scichina.com ) 的三角图解都可将沙漠区分.

(3) 西部沙漠与中西部沙漠是黄土物质潜在的源 区，上风向的西部沙漠高含量碳酸盐矿物是黄土高原 黄土含有丰富的碳酸盐矿物的可能原因.
致谢感谢中国科学院地球环境研究所孙有斌研究员提 供的蒙古戈壁地表样品. 野外工作得到了河海大学饶文 波教授以及南京大学王晓勇副教授、孟先强博士、何同 博士、达佳伟和李石磊等同仁的帮助, 特此致谢.

\section{参考文献}

陈骏, 安芷生, 刘连文, 季峻峰, 杨杰东, 陈旸. 2001. 最近2.5Ma以来 黄土高原风尘化学组成的变化与亚洲内陆的化学风化. 中国科 学D辑: 地球科学, 31: 136-145

陈骏, 李高军. 2011. 亚洲风尘系统地球化学示踪研究. 中国科学: 地 球科学, 41: 1211-1232

陈思宇, 黄建平, 李景金, 贾瑞, 江南萱, 康丽泰, 马骁骏, 谢亭亭. 2017. 塔克拉玛干沙漠和戈壁沙尘起沙、传输和沉降的对比研 究. 中国科学: 地球科学, 47: 939-957

方小敏, 吕连清, 杨胜利, 李吉均, 安芷生, 蒋平安, 陈秀玲. 2001. 昆 仑山黄土与中国西部沙漠发育和高原隆升. 中国科学 $\mathrm{D}$ 辑: 地球 科学, 31: 177-184

付旭东, 王岩松. 2015. 中国沙漠物源研究: 回顾与展望. 沉积学报, 33: $1063-1073$

付旭东, 杨小平. 2004. 中国北方沙漠石英 $\delta^{18} \mathrm{O}$ 值的初步测定与分析. 第四纪研究, 24: 243

郭正堂. 2017. 黄土高原见证季风和荒漠的由来. 中国科学 $\mathrm{D}$ 辑: 地球 科学, 47: 421-437

郭正堂, 彭淑贞. 2001. 风尘堆积中 $\mathrm{SiO}_{2} / \mathrm{Al}_{2} \mathrm{O}_{3}$ 值与粒度的关系及其 对东亚冬季风的指示意义. 中国科学 $\mathrm{D}$ 辑: 地球科学, 31(增刊): 209-214

霍俊澎, 郭浩, 郭翠萍, 辛智鸣. 2018. 中国主要沙漠(沙地)的氧同位 素含量特征. 干早区研究, 35: 471-476

季峻峰, 王洪涛, 陈骏. 1997. 陕西洛川黄土-古土壤剖面中伊利石结 晶度一一黄土物质来源和古气候环境指示. 地质评论, 43: 181185

李高军. 2010. 东亚风尘物源地球化学示踪研究. 博士学位论文. 南 京: 南京大学

刘东生. 1985. 黄土与环境. 北京: 科学出版社

刘嘉琪, 秦小光. 2005. 塔里木盆地的环境格局与绿洲演化. 第四纪 研究, 25: 533-539

刘连文. 2002. 3.6Ma来黄土高原中国季风演化的矿物与元素地球化 学研究. 博士学位论文. 南京: 南京大学

刘连文, 陈骏, 王洪涛, 陈䀛. 2000. 一个不受风力分选作用影响的化 学风化指标: 黄土酸不溶物中的Fe/Mg值. 科学通报, 46: 579-582 刘训, 李廷栋, 耿树方, 游国庆. 2012. 中国大地构造区划及若干问题. 地质通报, 31: 1024-1034

鹿化显, 郭正堂. 2013. 晚新生代东亚气候变化: 进展与问题. 中国科 学: 地球科学, 43: 1907-1918

罗万银, 董治宝, 钱广强, 冯益明, 逯军峰, 王蒙, 任小玢, 李继彦. 
2014. 戈壁表层沉积物地球化学元素组成及其沉积意义. 中国沙 漠, 34: 1441-1453

潘桂棠, 肖庆辉, 陆松年, 邓晋福, 冯益民, 张克信, 张智勇, 王方国, 邢光福, 郝国杰, 冯艳芳. 2009. 中国大地构造单元划分. 中国地 质, 36: 1-28

饶文波, 杨杰东, 陈骏, 李高军. 2006. 中国干旱-半干旱区风尘物质的 $\mathrm{Sr}, \mathrm{Nd}$ 同位素地球化学: 对黄土来源和季风演变的指示. 科学通 报, 51: 25-38

强小科, 安芷生, 宋友桂, 常宏, 孙有斌, 刘卫国, 敖红, 董吉宝, 符超 峰, 吴枫, 卢凤艳, 蔡演军, 周卫健, 曹军䩀, 徐新文, 艾莉. 2010. 晚 渐新世以来中国黄土高原风成红粘土序列的发现：亚洲内陆干 旱化起源的新记录. 中国科学: 地球科学, 40: 1469-1488

王国灿, 曹凯, 张克信, 王岸, 刘超, 孟艳宁, 徐亚东. 2011. 青藏高原 新生代构造隆升阶段的时空格局. 中国科学: 地球科学, 41: 332349

王立强, 王亲. 2013. 河西走廊及其毗邻地区地表物沉积元素特征. 西北地质, 46: 69-80

谢静, 丁仲礼. 2007. 中国东北部沙地重矿物组成及沙源分析. 中国 科学 D辑: 地球科学, 37: 1065-1072

谢学锦. 2012. 中国地球化学图集. 北京: 地质出版社

辛后田, 王惠初, 周世军. 2006. 柴北缘的大地构造演化及其地质事 件群. 地质调查与研究, 29: 311-320

杨杰东, 陈骏, 饶文波, 李高军, 季峻峰. 2007. 中国沙漠同位素分区 特征. 地球化学, 36: 516-524

张峰, 付旭东. 2016. 塔克拉玛干沙漠石英氧同位素与粒级关系的研 究. 地质论评, 62: 73-82

朱震达, 吴正, 刘恕, 邸醒民. 1980. 中国沙漠概论(修订版). 北京: 科 学出版社

Bauluz B, Mayayo M J, Fernandez-Nieto C, Gonzalez Lopez J M. 2000. Geochemistry of Precambrian and Paleozoic siliciclastic rocks from the Iberian Range (NE Spain): Implications for source-area weathering, sorting, provenance, and tectonic setting. Chem Geol, 168: $135-150$

Badarch G, Dickson Cunningham W, Windley B F. 2002. A new terrane subdivision for Mongolia: Implications for the Phanerozoic crustal growth of Central Asia. J Asian Earth Sci, 21: 87-110

Blatt H, Middleton G, Murray R. 1972. Origin of Sedimentary Rocks. Englewood Cliffs: Prentice-Hall

Chen J, LiG J, Yang J D, Rao W B, Lu H Y, Balsam W, Sun Y B, Ji J F. 2007. $\mathrm{Nd}$ and $\mathrm{Sr}$ isotopic characteristics of Chinese deserts: Implications for the provenances of Asian dust. Geochim Cosmochim Acta, 71: 3904-3914

Engelbrecht J P, Derbyshire E. 2010. Airborne mineral dust. Elements, 6: $241-246$

Guo Z T, Ruddiman W F, Hao Q Z, Wu H B, Qiao Y S, Zhu R X, Peng S Z, Wei J J, Yuan B Y, Liu T S. 2002. Onset of Asian desertification by $22 \mathrm{Myr}$ ago inferred from loess deposits in China. Nature, 416: 159-163

He T, Liu L, Chen Y, Sheng X, Ji J. 2016. Plagioclase sub-species in Chinese loess deposits: Implications for dust source migration and past climate change. Quat Res, 85: 17-24

Honda M, Shimizu H. 1998. Geochemical, mineralogical and sedimentological studies on the Taklimakan Desert sands. Sedimentology, 45: 1125-1143

Hu F G, Yang X P. 2016. Geochemical and geomorphological evidence for the provenance of Aeolian deposits in the Badain Jaran Desert, northwestern China. Quat Sci Rev, 131: 179-192

Jeong G Y, Hillier S, Kemp R A. 2008. Quantitative bulk and singleparticle mineralogy of a thick Chinese loess-paleosol section: Implications for loess provenance and weathering. Quat Sci Rev, 27: 1271-1287

Li L, Chen J, Chen Y, Hedding D W, Li T, Li L, Liu X, Zeng F, Wu W, Zhao L, Li G. 2018. Uranium isotopic constraints on the provenance of dust on the Chinese Loess Plateau. Geology, 46: 747-750

Li G J, Chen J, Chen Y, Yang J D, Ji J F, Liu L W. 2007. Dolomite as a tracer for the source regions of Asian dust. J Geophys Res, 112: D17201

Liu B, Jin H, Sun Z, Zhao S. 2016. Geochemical weathering of Aeolian sand and its palaeoclimatic implications in the $\mathrm{Mu}$ Us Desert, northern China, since the Late Holocene. J Arid Land, 8: 647-659

Liu C Q, Masuda A, Okada A, Yabuki S, Zhang J, Fan Z L. 1993. A geochemical study of loess and desert sand in northern China: Implications for continental crust weathering and composition. Chem Geol, 106: 359-374

Liu C Q, Masuda A, Okada A, Yabuki S, Fan Z L. 1994. Isotope geochemistry of Quaternary deposits from the arid lands in Northern China. Earth Planet Sci Lett, 127: 25-38

Liu J Q, Chen L H, Zeng G, Wang X J, Zhong Y, Yu X. 2016. Lithospheric thickness controlled compositional variations in potassic basalts of Northeast China by melt-rock interactions. Geophys Res Lett, 43: 2582-2589

Liu Z, Yang X P. 2013. Geochemical-geomorphological evidence for the provenance of Aeolian sands and sedimentary environments in the Hunshandake Sandy Land, Eastern Inner Mongolia, China. Acta Geol Sin-Engl Ed, 87: 871-884

Lu W Y, Zhao W C B, WLu H Y, Liu P, Lu Z L, Ji J F. 2017. Iron mineralogy and speciation in clay-sized fractions of Chinese desert sediments. J Geophys Res-Atmos, 122: 13,458-13,471

Maher B A, Mutch T J, Cunningham D. 2009. Magnetic and geochemical characteristics of Gobi Desert surface sediments: Implications for provenance of the Chinese Loess Plateau. Geology, 37: $279-282$ 
Meng X Q, Liu L W, Balsam W, Li S L, He T, Chen J, Ji J F. 2015. Dolomite abundance in Chinese loess deposits: A new proxy of monsoon precipitation intensity. Geophys Res Lett, 42: 1039110398

Muhs D R. 2004. Mineralogical maturity in dunefields of North America, Africa and Australia. Geomorphology, 59: 247-269

Nesbitt H, Young G. 1996. Petrogenesis of sediments in the absence of chemical weathering: Effects of abrasion and sorting on bulk composition and mineralogy. Sedimentology, 43: 341-358

Pettijohn F J, Potter P E, Siever R. 1972. Sand and Sandstone. New York: Springer-Verlag

Potter P E, Huh Y, Edmond J M. 2001. Deep-freeze petrology of Lena River sand, Siberia. Geology, 29: 999

Pullen A, Kapp P, McCallister A T, Chang H, Gehrels G E, Garzione C N, Heermance R V, Ding L. 2011. Qaidam Basin and northern Tibetan Plateau as dust sources for the Chinese Loess Plateau and paleoclimatic implications. Geology, 39: 1031-1034

Ren X Z, Yang X P, Wang Z T, Zhu B Q Z D G, Rioual P. 2014. Geochemical evidence of the sources of Aeolian sands and their transport pathways in the Minqin Oasis, northwestern China. Quat Int, 334-335: 165-178

Ruxton B P. 1968. Measures of the degree of chemical weathering of rocks. J Geol, 76: 518-527

Shao Y, Dong C H. 2006. A review on East Asian dust storm climate, modelling and monitoring. Glob Planet Change, 52: 1-22

Smalley I. 1995. Making the material: The formation of silt sized primary mineral particles for loess deposits. Quat Sci Rev, 14: 645651

Sun J. 2002. Provenance of loess material and formation of loess deposits on the Chinese Loess Plateau. Earth Planet Sci Lett, 203: $845-859$

Sun Y, Chen H, Tada R, Weiss D, Lin M, Toyoda S, Yan Y, Isozaki Y. 2013. ESR signal intensity and crystallinity of quartz from Gobi and sandy deserts in East Asia and implication for tracing Asian dust provenance. Geochem Geophys Geosyst, 14: 2615-2627

Sun Y, Tada R, Chen J, Chen H, Toyoda S, Tani A, Isozaki Y, Nagashima K, Hasegawa H, Ji J. 2007. Distinguishing the sources of Asian dust based on electron spin resonance signal intensity and crystallinity of quartz. Atmos Environ, 41: 8537-8548
Tapponnier P, Molnar P. 1976. Slip-line field theory and large-scale continental tectonics. Nature, 264: 319-324

Wang X, Xia D, Zhang C, Lang L, Hua T, Zhao S. 2012. Geochemical and magnetic characteristics of fine-grained surface sediments in potential dust source areas: Implications for tracing the provenance of Aeolian deposits and associated palaeoclimatic change in East Asia. Palaeogeogr Palaeoclimatol Palaeoecol, 323-325: 123132

Wang Y Q, Zhang X Y, Arimoto R, Cao J J, Shen Z X. 2005. Characteristics of carbonate content and carbon and oxygen isotopic composition of northern China soil and dust aerosol and its application to tracing dust sources. Atmos Environ, 39: 2631-2642

Xie Y, Chi Y. 2016. Geochemical investigation of dry- and wetdeposited dust during the same dust-storm event in Harbin, China: Constraint on provenance and implications for formation of Aeolian loess. J Asian Earth Sci, 120: 43-61

Xiong S, Ding Z, Zhu Y, Zhou R, Lu H. 2010. A 6 Ma chemical weathering history, the grain size dependence of chemical weathering intensity, and its implications for provenance change of the Chinese loess-red clay deposit. Quat Sci Rev, 29: 1911-1922

Xu Z, Lu H, Zhao C, Wang X, Su Z, Wang Z, Liu H, Wang L, Lu Q. 2011. Composition, origin and weathering process of surface sediment in Kumtagh Desert, Northwest China. J Geogr Sci, 21: $1062-1076$

Yang X, Zhu B, White P D. 2007. Provenance of Aeolian sediment in the Taklamakan Desert of western China, inferred from REE and major-elemental data. Quat Int, 175: 71-85

Zhao W, Sun Y, Balsam W, Lu H, Liu L, Chen J, Ji J. 2014. Hf-Nd isotopic variability in mineral dust from Chinese and Mongolian deserts: Implications for sources and dispersal. Sci Rep, 4: 5837

Zheng H. 2016. Asia dust production ramped up since latest Oligocene driven by Tibetan Plateau uplift. Natl Sci Rev, 3: 271-274

Zheng H, Wei X, Tada R, Clift P D, Wang B, Jourdan F, Wang P, He M. 2015. Late Oligocene-early Miocene birth of the Taklimakan Desert. Proc Natl Acad Sci USA, 112: 7662-7667

Zheng Y F, Xiao W J, Zhao G. 2013. Introduction to tectonics of China. Gondwana Res, 23: 1189-1206

Zhu B, Yang X. 2009. Chemical weathering of detrital sediments in the Taklamakan Desert, Northwestern China. Geogr Res, 47: 57-70

(责任编委: 吴海斌) 